\title{
Toward Building a Physical Proxy for Gas-Phase Sulfuric Acid Concentration Based on Its Budget Analysis in Polluted Yangtze River Delta, East China
}

\section{Yang, Liwen}

2021-05-18

Yang , L, Nie , W , Liu , Y , Xu , Z, Xiao, M , Qi , X, Li , Y, Wang , R , Zou , J, Paasonen , P , Yan , C , Xu , Z, Wang, J , Zhou , C, Yuan , J, Sun , J , Chi , X, Kerminen , V-M , Kulmala, M \& Ding , A 2021 , ' Toward Building a Physical Proxy for Gas-Phase Sulfuric Acid Concentration Based on Its Budget Analysis in Polluted Yangtze River Delta, East China ', Environmental Science \& Technology , vol. 55 , no. 10 , pp. 6665-6676 . https://doi.org/10.1021/acs.est.1c0

http://hdl.handle.net/10138/332513

https://doi.org/10.1021/acs.est.1c00738

cc_by_nc_nd

publishedVersion

Downloaded from Helda, University of Helsinki institutional repository.

This is an electronic reprint of the original article.

This reprint may differ from the original in pagination and typographic detail.

Please cite the original version. 


\section{Toward Building a Physical Proxy for Gas-Phase Sulfuric Acid Concentration Based on Its Budget Analysis in Polluted Yangtze River Delta, East China}

Liwen Yang, Wei Nie,* Yuliang Liu, Zhengning Xu, Mao Xiao, Ximeng Qi, Yuanyuan Li, Ruoxian Wang, Jun Zou, Pauli Paasonen, Chao Yan, Zheng Xu, Jiaping Wang, Chen Zhou, Jian Yuan, Jianning Sun, Xuguang Chi, Veli-Matti Kerminen, Markku Kulmala, and Aijun Ding

Cite This: Environ. Sci. Technol. 2021, 55, 6665-6676

Read Online

ABSTRACT: Gaseous sulfuric acid $\left(\mathrm{H}_{2} \mathrm{SO}_{4}\right)$ is a crucial precursor for secondary aerosol formation, particularly for new particle formation (NPF) that plays an essential role in the global number budget of aerosol particles and cloud condensation nuclei. Due to technology challenges, global-wide and longterm measurements of gaseous $\mathrm{H}_{2} \mathrm{SO}_{4}$ are currently very challenging. Empirical proxies for $\mathrm{H}_{2} \mathrm{SO}_{4}$ have been derived mainly based on short-term intensive campaigns. In this work, we performed comprehensive measurements of $\mathrm{H}_{2} \mathrm{SO}_{4}$ and related parameters in the polluted Yangtze River Delta in East China during four seasons and developed a physical proxy based on the budget analysis of gaseous $\mathrm{H}_{2} \mathrm{SO}_{4}$. Besides the photo-oxidation of $\mathrm{SO}_{2}$, we found that primary emissions can contribute considerably, particularly at night. Dry deposition has the potential to be a non-negligible sink, in addition to condensation onto particle surfaces. Compared with the empirical proxies, the newly developed

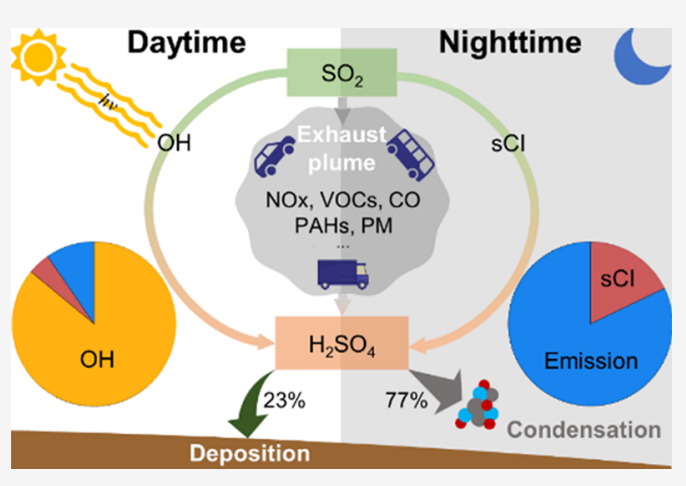
physical proxy demonstrates extraordinary stability in all the seasons and has the potential to be widely used to improve the understanding of global NPF fundamentally.

KEYWORDS: sulfuric acid, proxy, budget analysis, primary emission, dry deposition

\section{INTRODUCTION}

Atmospheric aerosols play an essential role in air quality, ${ }^{1}$ human health, ${ }^{2}$ and climate change. ${ }^{3}$ New particle formation (NPF), which can be observed worldwide, ${ }^{4}$ determines the global budget of aerosol particles in terms of their number concentrations. ${ }^{5}$ Gaseous sulfuric acid $\left(\mathrm{H}_{2} \mathrm{SO}_{4}\right)$ is the key precursor for particle nucleation via a series of processes, including $\mathrm{H}_{2} \mathrm{SO}_{4}-\mathrm{H}_{2} \mathrm{O}$ binary nucleation, $\mathrm{H}_{2} \mathrm{SO}_{4}$-ammonia $\left(\mathrm{NH}_{3}\right)-\mathrm{H}_{2} \mathrm{O}$ ternary nucleation, ${ }^{6,7} \mathrm{H}_{2} \mathrm{SO}_{4}$-amines $-\mathrm{H}_{2} \mathrm{O}$ nucleation, ${ }^{8,9} \mathrm{H}_{2} \mathrm{SO}_{4}$-organic $-\mathrm{H}_{2} \mathrm{O}$ nucleation, ${ }^{10,11}$ and $\mathrm{H}_{2} \mathrm{SO}_{4}-\mathrm{NH}_{3}$-organic nucleation. ${ }^{12}$ However, measuring gaseous $\mathrm{H}_{2} \mathrm{SO}_{4}$ has been challenging due to its extremely low atmospheric concentrations. Long-term measurements of ambient $\mathrm{H}_{2} \mathrm{SO}_{4}$ have only been reported in very few studies, ${ }^{13-18}$ which limits the understanding of global NPF.

Gaseous $\mathrm{H}_{2} \mathrm{SO}_{4}$ was long believed to be formed only from the reaction between $\mathrm{SO}_{2}$ and $\mathrm{OH}$. More recently, stabilized Criegee intermediates ( $\mathrm{sCI}$ ), formed in the ozonolysis of alkenes, were demonstrated to be able to oxidize $\mathrm{SO}_{2}$ and contribute to gaseous $\mathrm{H}_{2} \mathrm{SO}_{4} \cdot{ }^{19,20}$ This was found to be particularly important for the nighttime $\mathrm{H}_{2} \mathrm{SO}_{4}$ formation. ${ }^{21}$ In the coastal marine atmosphere, $\mathrm{SO}_{2}$ oxidation by small Criegee intermediates (CI), produced possibly in photochemical reactions, and $\mathrm{SO}_{3}$ formed from dimethyl sulfide (DMS) oxidation reaction with water might be non-negligible sources of $\mathrm{H}_{2} \mathrm{SO}_{4}{ }^{17,22,23}$ Recently, Olin et al. ${ }^{24}$ indicated a potential source of $\mathrm{H}_{2} \mathrm{SO}_{4}$ from traffic emissions in urban Helsinki based on the observed positive correlation between $\mathrm{H}_{2} \mathrm{SO}_{4}$ and $\mathrm{NO}_{x}$ concentrations. Because of its weak chemical reactivity, the main sinks for gaseous $\mathrm{H}_{2} \mathrm{SO}_{4}$ are expected to be condensation onto aerosol particles or dry deposition to the ground or other surfaces.

Several proxies for gaseous $\mathrm{H}_{2} \mathrm{SO}_{4}$ were developed to enhance our global understanding of $\mathrm{H}_{2} \mathrm{SO}_{4}$ and NPF. Petäjä et al. ${ }^{25}$ and Mikkonen et al. ${ }^{16}$ built such proxies by considering the $\mathrm{SO}_{2}-\mathrm{OH}$ reaction as the only source, and condensation onto pre-existing aerosol particles as the only sink, for $\mathrm{H}_{2} \mathrm{SO}_{4}$. $\mathrm{Lu}$ et al. ${ }^{26}$ took into account $\mathrm{O}_{3}$ and $\mathrm{HONO}$ concentrations to differentiate between $\mathrm{OH}$ originating from the $\mathrm{O}_{3}$ and $\mathrm{HONO}$

Received: February 1, 2021

Revised: April 11, 2021

Accepted: April 21, 2021

Published: May 7, 2021

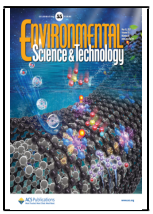


photolysis. Dada et al. ${ }^{18}$ added the reaction of $\mathrm{SO}_{2}$ with $\mathrm{sCI}$ as an additional $\mathrm{H}_{2} \mathrm{SO}_{4}$ source to the proxy. These efforts largely improved the understanding of $\mathrm{H}_{2} \mathrm{SO}_{4}$ in different environments, however, with obvious limitations. First, they all are empirical proxies based on mainly short-term and site-specific measurements, casting doubts on their general applicability. Second, nighttime $\mathrm{H}_{2} \mathrm{SO}_{4}$ is rarely considered in these proxies. Here, we carried out comprehensive measurements of $\mathrm{H}_{2} \mathrm{SO}_{4}$ and related parameters during four seasons at the SORPES station, East China, and conducted a budget analysis for gaseous $\mathrm{H}_{2} \mathrm{SO}_{4}$ by taking all possible sources and sinks into consideration. We then developed a new physical proxy accordingly and evaluated its stability during different seasons.

\section{MATERIALS AND METHODS}

Field Observations. The observations were carried out at the Station for Observing Regional Processes of the Earth System (SORPES) in the northeastern part of Nanjing, China $\left(118^{\circ} 57^{\prime} \mathrm{E}, 32^{\circ} 07^{\prime} \mathrm{N}\right)$, which is the regional background station upwind from downtown Nanjing, during winter (from December 11, 2017, to January 17, 2018), spring (from April 13, 2018, to April 23, 2018), summer (from July 11, 2018, to August 9, 2018), and autumn (all of November 2018). The surrounding environment of the site is given in Figure S1 and detailed descriptions can be found elsewhere. ${ }^{27-31}$

$\mathrm{H}_{2} \mathrm{SO}_{4}$ was measured with a chemical ionization mass spectrometer (CIMS) equipped with a nitrate ionization source. ${ }^{32}$ Ambient $\mathrm{H}_{2} \mathrm{SO}_{4}$ molecules were charged by reacting with $\mathrm{NO}_{3}{ }^{-}$reagent ions in the reaction chamber of the inlet. Then, the concentration is calculated from the measured ion signals according to:

$$
\left[\mathrm{H}_{2} \mathrm{SO}_{4}\right]=\mathrm{C}\left[\frac{\mathrm{HSO}_{4}^{-}+\mathrm{HSO}_{4}^{-} \cdot \mathrm{HNO}_{3}}{\mathrm{NO}_{3}^{-}+\mathrm{HNO}_{3} \cdot \mathrm{NO}_{3}^{-}+\mathrm{HNO}_{3} \cdot\left(\mathrm{HNO}_{3}\right) \mathrm{NO}_{3}^{-}}\right]
$$

where $C$ is the calibration coefficient, which was obtained seasonally by the known concentration of $\mathrm{H}_{2} \mathrm{SO}_{4}$ calculated from the $\mathrm{SO}_{2}-\mathrm{OH}$ reaction here with $33 \%$ systematic uncertainty. ${ }^{33}$ Also, this instrument provides a high signal-tonoise ratio and the limit of detection for $\mathrm{H}_{2} \mathrm{SO}_{4}$ was reported to be close to $2 \times 10^{4} \mathrm{~mol} / \mathrm{cm}^{3}$. 32

During the whole four campaigns, we measured benzene and isoprene by proton-transfer-reaction mass spectrometry ${ }^{34}$ (PTR-ToF-MS). Trace gases $\left(\mathrm{SO}_{2}, \mathrm{O}_{3}, \mathrm{NO}_{x}\right.$, and $\left.\mathrm{CO}\right)$ were measured continuously using a Thermo TEI 43i, TEI 49i, TEI $42 \mathrm{i}$, and TEI 48i, respectively. Typical anthropogenic alkenes were obtained by gas chromatography and mass spectrometry $^{35}$ (TT24-2 GCMS) from November 26, 2019, to January 4, 2020. Ultraviolate B (UVB) radiation intensity was measured using a radiometer (Kipp \& Zonen UVS-B-T). Wind speeds were measured at six levels using GILL Wind Sonic, and here, we used data from the height of $4 \mathrm{~m}$. The particle number size distribution between 6 and $800 \mathrm{~nm}$ was measured using a differential mobility particle sizer (DMPS), and for the sub- 6 $\mathrm{nm}$ particle and particles larger than $800 \mathrm{~nm}$, a scanning mobility particle sizer (SMPS, 4-495.8 nm) and aerodynamic particle sizer (APS, 0.54-19.8 $\mu \mathrm{m}$ ) were used respectively from January 1, 2019, to June 30, 2019. In this work, the daytime window was defined from 08:00 to $16: 00$ and the nighttime window from 20:00 to $04: 00$ on the following day. In addition to the correlation coefficient $(R)$, the relative error
(RE) is used to evaluate the performance of proxies in the statistical analysis and can be written as follows:

$$
\mathrm{RE}=\left(\frac{\left|X_{\text {proxy }}-X_{\text {meas }}\right|}{X_{\text {meas }}}\right)_{0.5}
$$

Here, $X$ denotes the selected species and the subscript of 0.5 denotes the median number. More details are described in the Supporting Information.

Calculation Methods. The Proxy of Alkenes. Long-term measurement of complex alkenes is challenging, especially for those from anthropogenic sources. In this study, volatile organic compounds (VOCs) were measured simultaneously with $\mathrm{H}_{2} \mathrm{SO}_{4}$ during four seasons using PTR-ToF-MS, which is not sensitive to short-chain alkenes. Therefore, we derived a proxy based on a relatively short-term GC-MS measurement, during which ethylene, propene, and 1-butene were the dominating anthropogenic species and correlated linearly to benzene (Figure S3) with the slope of 1.922 and relative error of $28.2 \%$. Since the estimated isoprene emissions are much larger than those of monoterpenes over the Yangtze River Delta, ${ }^{36}$ we used isoprene concentration to represent the total biogenic alkenes. Therefore, the total alkene concentration can be obtained by the following equation:

$$
\text { [alkenes }]=1.922[\text { benzene }]+[\text { isoprene }]
$$

Calculation of Dry Deposition. Dry deposition, as the ultimate path by which trace gases and particles are removed from the atmosphere in the absence of precipitation, is governed by three factors: atmospheric turbulence, the physical and chemical properties of the depositing species, and the nature of the surface. Since simulating such a variety of complex processes is generally impractical, dry deposition is usually simplified as a single parameter, the deposition velocity $\left(V_{\mathrm{d}}\right)$.

Here, a dry deposition resistance model ${ }^{37}$ was used to estimate the deposition losses of $\mathrm{H}_{2} \mathrm{SO}_{4}$ indirectly based on measurements by an eddy-covariance system (EC3000, Campbell Scientific) at the height of $3 \mathrm{~m}$. For gases, $V_{\mathrm{d}}$ in this dry deposition model is computed from a formula analogous to Ohm's law in electrical circuits: ${ }^{38}$

$$
V_{\mathrm{d}}^{\mathrm{i}}=\left(R_{\mathrm{a}}+R_{\mathrm{b}}^{\mathrm{i}}+R_{\mathrm{c}}^{\mathrm{i}}\right)^{-1}
$$

The term $R_{a}$ governed by turbulent transport, represents aerodynamic resistance and $R_{\mathrm{b}}^{\mathrm{i}}$ represents the quasi-laminar resistance dependent on molecular properties of the substance and surface characteristics. $R_{\mathrm{c}}^{\mathrm{i}}$ is the surface resistance, but it is negligible for $\mathrm{H}_{2} \mathrm{SO}_{4}$ due to its extremely high Henry's law coefficient. The detailed calculation can be found in the Supporting Information.

Calculation of Condensation Sink (CS). CS was calculated using the method proposed by Kulmala et al. ${ }^{39}$ based on measurements of the particle number size distribution between 6 and $800 \mathrm{~nm}$ using DMPS. Also, the contribution of sub- $6 \mathrm{~nm}$ particles and particles larger than $800 \mathrm{~nm}$ to CS was estimated to be less than $10 \%$ based on measurements of SMPS and APS from January 1, 2019, to June 30, 2019, as described in the Supporting Information.

Simulation of Clustering Processes. Due to the lack of most $\mathrm{H}_{2} \mathrm{SO}_{4}$ clusters measurements, a kinetic model was used to estimate clustering processes. The distribution of molecular clusters in acid-base nucleation can be simulated using the 

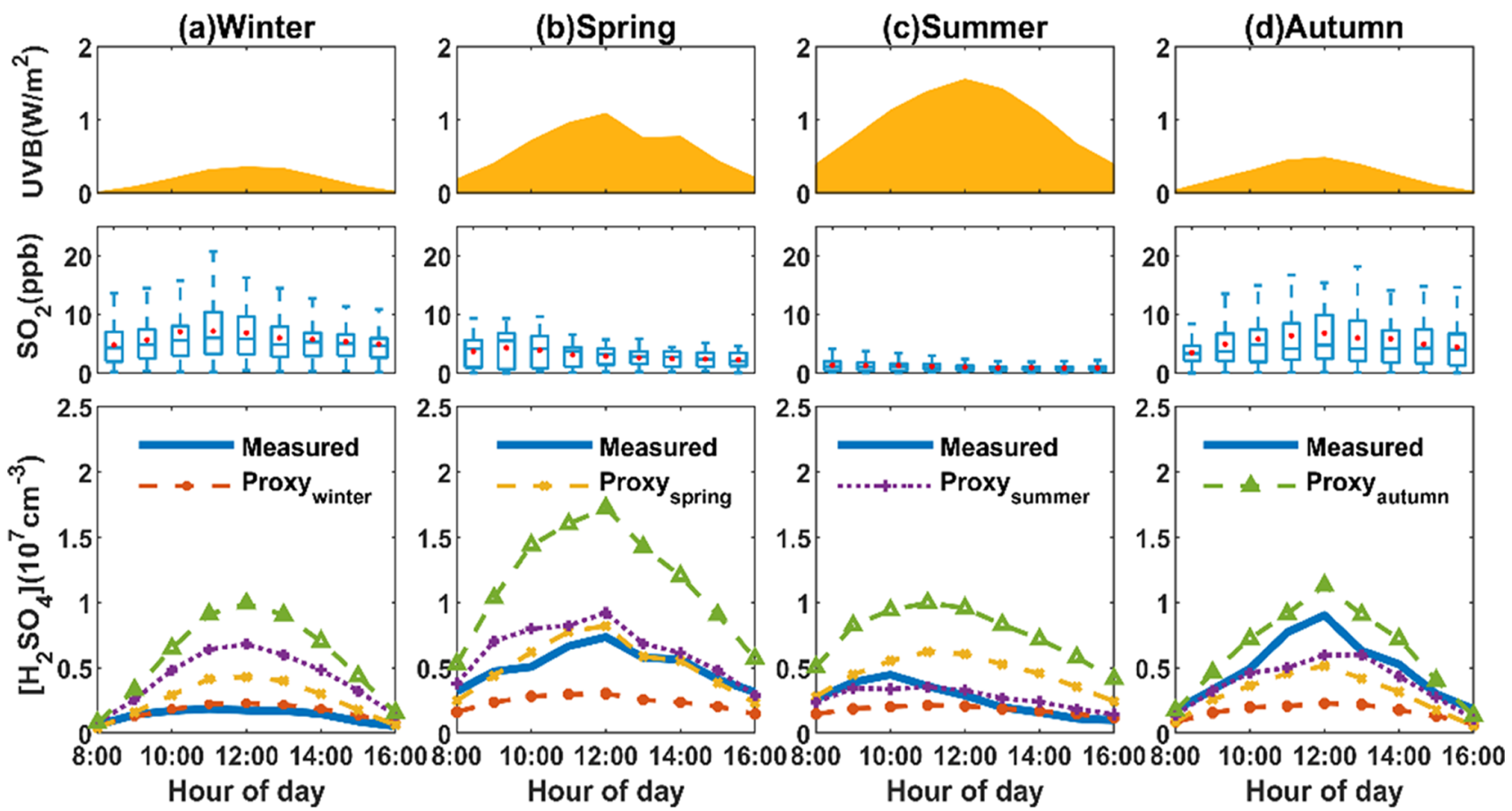

Figure 1. Daytime variation of $\mathrm{UVB}, \mathrm{SO}_{2}$, measured $\mathrm{H}_{2} \mathrm{SO}_{4}$, and calculated $\mathrm{H}_{2} \mathrm{SO}_{4}$ by empirical formulas in (a) winter, (b) spring, (c) summer, and (d) autumn. The daytime window is defined from 08:00 to 16:00. The levels of $\mathrm{UVB}$ and $\mathrm{H}_{2} \mathrm{SO}_{4}$ are displayed as their median concentrations. The blue horizontal lines show the median $\mathrm{SO}_{2}$, blue boxes show 25th and 75th percentile values, and whiskers show outlier cutoffs. The red points show the mean concentration of $\mathrm{SO}_{2}$. The bottom panel shows measured $\mathrm{H}_{2} \mathrm{SO}_{4}$ and calculated $\mathrm{H}_{2} \mathrm{SO}_{4}$ from four proxies based on different seasons. Blue lines, orange dotted lines, yellow dotted lines, purple dotted lines, and green dotted lines denote measured $\mathrm{H}_{2} \mathrm{SO}_{4}$ and calculated $\mathrm{H}_{2} \mathrm{SO}_{4}$ based on Proxy $_{\text {winter, }}$ Proxy $_{\text {spring }}$, Proxy summer $_{2}$ and Proxy $_{\text {autumn }}$, respectively. We provide a time series of related parameters in Figure S2, including $\mathrm{UVB}, \mathrm{PM}_{2.5}, \mathrm{NO}_{x}, \mathrm{O}_{3}, \mathrm{SO}_{2}$, and $\mathrm{H}_{2} \mathrm{SO}_{4}$.

explicit solution of the general dynamic equations. Detailed descriptions for the model can be found elsewhere. ${ }^{40}$

Estimation of Hydroxyl Radical $(\bullet \mathrm{OH})$. For the difficulty to measure the $\mathrm{OH}$ radical continuously, we calculated the daytime $\mathrm{OH}$ concentration by applying the empirical formula proposed by Rohrer and Berresheim, ${ }^{41}$ which demonstrated that the $\mathrm{OH}$ radical is linearly correlated to the photolysis frequency $J\left(\mathrm{O}^{1} \mathrm{D}\right)$. We calculated $J\left(\mathrm{O}^{1} \mathrm{D}\right)$ using the tropospheric ultraviolet and visible (TUV) radiation model and corrected it by the observed UVB. ${ }^{42}$ Detailed information can be found in the Supporting Information.

\section{RESULTS AND DISCUSSION}

Overall Observations and Empirical Formula. Seasonal patterns of the daytime $\mathrm{H}_{2} \mathrm{SO}_{4}$ concentration and related parameters are illustrated in Figure 1. The median daytime concentrations of $\mathrm{H}_{2} \mathrm{SO}_{4}$ were significantly higher in autumn $\left(9.02 \times 10^{6} \mathrm{~cm}^{-3}\right)$ and spring $\left(7.35 \times 10^{6} \mathrm{~cm}^{-3}\right)$ than in summer $\left(4.47 \times 10^{6} \mathrm{~cm}^{-3}\right)$ and winter $\left(1.85 \times 10^{6} \mathrm{~cm}^{-3}\right)$. A typical diurnal cycle shows the noontime peaks of $\mathrm{H}_{2} \mathrm{SO}_{4}$ to follow UVB in spring, autumn, and winter. In summer, $\mathrm{SO}_{2}$ concentrations, owing to the long-term emission reduction in China, ${ }^{31}$ were low enough to be the limiting factor for $\mathrm{H}_{2} \mathrm{SO}_{4}$ production, and the resulting $\mathrm{H}_{2} \mathrm{SO}_{4}$ concentration peaked at about 10:00 am when $\mathrm{SO}_{2}$ had its maximum value. We then used a traditional approach analogous to most previous works, developed empirical proxies of $\mathrm{H}_{2} \mathrm{SO}_{4}$ separately for the four seasons, and verified their suitability. Note that the traditional proxy excludes the formation of $\mathrm{H}_{2} \mathrm{SO}_{4}$ in the oxidation by $\mathrm{sCI}$ and, therefore, we only derived the daytime $\mathrm{H}_{2} \mathrm{SO}_{4}$ proxy. The proxy formula is as follows:

$$
\left[\mathrm{H}_{2} \mathrm{SO}_{4}\right]=k_{0}\left[\mathrm{SO}_{2}\right]^{a} \mathrm{CS}^{b} \mathrm{UVB}^{c}
$$

In Table S1, we summarize the proxy parameters of this work and previous studies. We can see that the fitting parameters $\left(k_{0}, a, b\right.$, and $\left.c\right)$ vary remarkably from site to site, as well as between the different seasons, challenging their general applicability. For example, the pre-exponential coefficient $k_{0}$ varied from 0.01 to $2.33 \times 10^{3}$. To verify this, we used the proxy obtained from the measurement in one season to the other three seasons, showing the results and relative errors in Figure 1 and Table S2. Comparisons between the four proxies are shown in Figure S5. It is obvious that the empirical proxy derived from one season cannot capture the variation of $\mathrm{H}_{2} \mathrm{SO}_{4}$ in the other three seasons. Especially for Proxy autumn $_{\text {and }}$ Proxy $_{\text {winter, }}$ they either greatly overestimate or underestimate the $\mathrm{H}_{2} \mathrm{SO}_{4}$ concentration for the other campaigns, causing significant relative errors (even up to 240\%). Furthermore, since these parameters are obtained from a mathematical fitting and are not independent of each other, the empirical proxy would not help understand the budget of $\mathrm{H}_{2} \mathrm{SO}_{4}$. Our results suggest that the empirical proxy has strong limitations and is incapable of being widely used.

Budget Analysis. Based on current knowledge, gaseous $\mathrm{H}_{2} \mathrm{SO}_{4}$ can only be formed from the reactions of $\mathrm{SO}_{2}$ with $\mathrm{OH}$ or $\mathrm{sCI}$, and it can be lost to aerosol surfaces (condensation sink), ground surface (dry deposition), and newly formed particles by forming $\mathrm{H}_{2} \mathrm{SO}_{4}$ clusters. Given a very short lifetime, the budget of $\mathrm{H}_{2} \mathrm{SO}_{4}$ can be described by the following equation 


$$
\begin{aligned}
\frac{\mathrm{d}\left[\mathrm{H}_{2} \mathrm{SO}_{4}\right]}{\mathrm{d} t}= & k_{1}\left[\mathrm{O}_{3}\right][\text { alkenes }]\left[\mathrm{SO}_{2}\right]+k_{2} J\left(\mathrm{O}^{1} \mathrm{D}\right)\left[\mathrm{SO}_{2}\right] \\
& -\mathrm{CS}\left[\mathrm{H}_{2} \mathrm{SO}_{4}\right]-\operatorname{Dep}\left[\mathrm{H}_{2} \mathrm{SO}_{4}\right]-\beta\left[\mathrm{H}_{2} \mathrm{SO}_{4}\right]^{2}
\end{aligned}
$$

During the daytime, the $\mathrm{H}_{2} \mathrm{SO}_{4}$ formation is dominated by the oxidation of $\mathrm{SO}_{2}$ by $\mathrm{OH}$, which is extremely difficult to be measured but has been demonstrated to be well reproduced by $J\left(\mathrm{O}^{1} \mathrm{D}\right) .^{41}$ During the nighttime, $\mathrm{SO}_{2}$ oxidation by $\mathrm{sCI}$ and $\mathrm{OH}$, produced from the ozonolysis of alkenes, is believed to control the formation of $\mathrm{H}_{2} \mathrm{SO}_{4}{ }^{21}$ In polluted urban areas, alkenes have complex species, and it is generally impractical to make long-term, full-spectrum measurements. Therefore, the alkene ozonolysis source is simplified to be a "bulk" item, being expressed as $k_{1}\left[\mathrm{O}_{3}\right]$ [alkenes] $\left[\mathrm{SO}_{2}\right]$. Here, $k_{1}$ is an apparent reaction rate constant that takes into account the rate constants between $\mathrm{O}_{3}$ and alkenes, the yield of $\mathrm{OH}$ radical and $\mathrm{sCI}$, and their reaction with $\mathrm{SO}_{2}$.

Most previous studies considered CS as the only important sink for gaseous $\mathrm{H}_{2} \mathrm{SO}_{4}$. However, the measurement site of $\mathrm{H}_{2} \mathrm{SO}_{4}$ is usually close to a ground surface (as well as other surfaces) so that dry deposition has the potential to be an important sink. Here, we estimated the loss of $\mathrm{H}_{2} \mathrm{SO}_{4}$ via dry deposition with a resistance model. Due to the extremely high Henry's law coefficient of $\mathrm{H}_{2} \mathrm{SO}_{4}$, its dry deposition is limited by atmospheric turbulence. Accurate micrometeorological parameters are needed, especially the friction velocity, which was measured in real time based on the eddy-covariance system in our experiments. We found that the calculated $\mathrm{H}_{2} \mathrm{SO}_{4}$ loss onto the ground surface could be up to $30 \%$ of that onto aerosol particles with the sampling inlet height of $1.5 \mathrm{~m}$, suggesting a considerable sink for the near-surface $\mathrm{H}_{2} \mathrm{SO}_{4}$, particularly during the noontime when the boundary layer mixing tends to decrease CS while, at the same time, enhancing dry deposition (Figure 2).

In addition, clustering processes could be a considerable loss for the $\mathrm{H}_{2} \mathrm{SO}_{4}$ monomer but were difficult to be evaluated due to the limitation on measuring most clusters, i.e., $\left(\mathrm{H}_{2} \mathrm{SO}_{4}\right)_{>2} \cdot{ }^{7,11,43}$ Here, we deployed a kinetic model to simulate and estimate the clustering processes. ${ }^{40}$ Given that

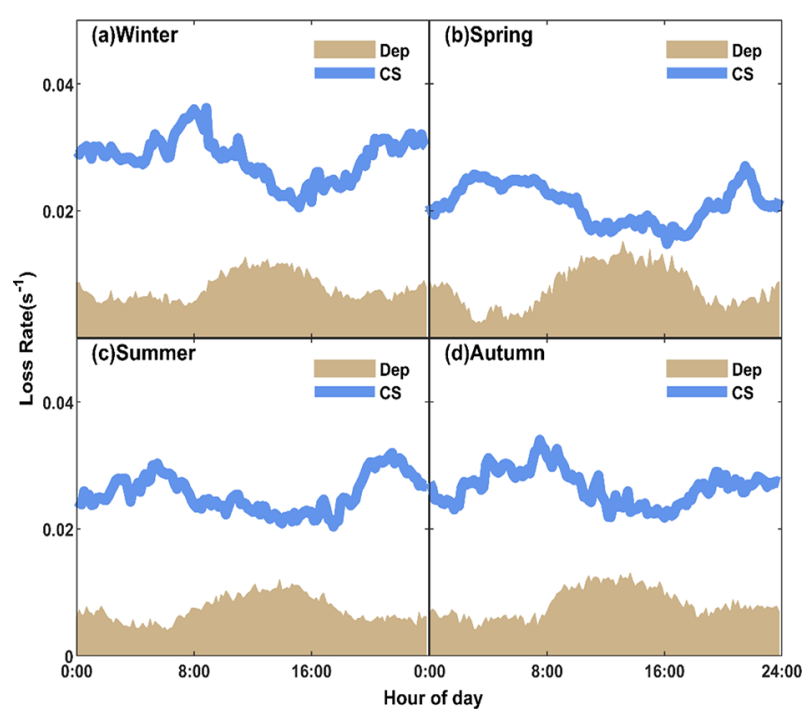

Figure 2. Diurnal variation of dry deposition rate and condensation sink in (a) winter, (b) spring, (c) summer, and (d) autumn. dimethylamine (DMA) is the crucial stabilizer to form $\mathrm{H}_{2} \mathrm{SO}_{4}$ clusters, especially in East China, ${ }^{8}$ we simulated the daytime clustering processes in four seasons with different DMA concentrations, as well as varied temperatures. The results showed that $\mathrm{H}_{2} \mathrm{SO}_{4}$ clustering processes at the SORPES station in summer and winter tended to the $10 \mathrm{ppt}$ DMA scenario, while spring and autumn matched the 5 ppt DMA scenario (Figure S6).

Clustering processes were simplified as $\beta\left[\mathrm{H}_{2} \mathrm{SO}_{4}\right]^{2}$. As shown in Figure 3, higher $\mathrm{H}_{2} \mathrm{SO}_{4}$ and DMA concentrations and lower CS and temperature tend to elevate the value of $\beta$. In our study, the majority of data points fall in the left side of the lines in Figure 3, where clustering losses contributed less than $10 \%$ of $\mathrm{CS}$ on removing the $\mathrm{H}_{2} \mathrm{SO}_{4}$ monomer. However, it was non-negligible in some time in spring, autumn, and winter. Therefore, we take this term into consideration in budget analysis, with $\beta$ of $5.69 \times 10^{-10} \mathrm{~cm}^{3} \mathrm{~s}^{-1}$ in winter, 1.37 $\times 10^{-10} \mathrm{~cm}^{3} \mathrm{~s}^{-1}$ in spring, $2.55 \times 10^{-11} \mathrm{~cm}^{3} \mathrm{~s}^{-1}$ in summer, and $1.15 \times 10^{-10} \mathrm{~cm}^{3} \mathrm{~s}^{-1}$ in autumn.

By assuming the $\mathrm{H}_{2} \mathrm{SO}_{4}$ concentration to be at a pseudosteady state (the left-hand side of eq 6 can be approximated to be zero), we fitted the data for the four seasons. The coefficients $k_{1}$ and $k_{2}$ were in the ranges of $2.21 \times 10^{-30}$ to 5.91 $\times 10^{-30} \mathrm{~cm}^{6} \mathrm{~s}^{-1}$ and $5.82 \times 10^{-2}$ to $18.00 \times 10^{-2}$, respectively (Table S3), i.e., they were relatively stable between the different seasons. The SORPES station is located on the southern edge of East China, and it can be influenced by both anthropogenic and biogenic emissions. ${ }^{29,30}$ Since anthropogenic alkenes consist mainly of short-chain alkenes, we could take these three above-mentioned dominating alkenes as representative examples of anthropogenic alkenes, and isoprene as a representative for biogenic alkenes, to estimate the range of $k_{1}$. The rate constants of the alkene $-\mathrm{O}_{3}$ reaction are $1.59 \times 10^{-18} \mathrm{~cm}^{3} \mathrm{~s}^{-1}$ for ethene, $1.01 \times 10^{-17} \mathrm{~cm}^{3} \mathrm{~s}^{-1}$ for propene, $9.64 \times 10^{-18} \mathrm{~cm}^{3} \mathrm{~s}^{-1}$ for 1-butene, and $1.28 \times 10^{-17}$ $\mathrm{cm}^{3} \mathrm{~s}^{-1}$ for isoprene. ${ }^{44}$ The rate constant of reaction between their derived $\mathrm{sCI}$ and $\mathrm{SO}_{2}$ varies from $2.4 \times 10^{-11}$ to $6.7 \times$ $10^{-11} \mathrm{~cm}^{3} \mathrm{~s}^{-1}, 45-48$ and the yield of $\mathrm{sCI}$ and $\mathrm{OH}$ radical varies from 0.17 to $0.56 .^{47,49-53}$ The unimolecular decomposition of $\mathrm{sCI}$ and reactions between $\mathrm{sCI}$ and atmospheric trace gas species, due to its strong chemical reactivity with them, result in a high loss rate of sCI, and we used the value of $32 \mathrm{~s}^{-1}$ for this loss rate based on previous studies. ${ }^{51,54}$ Therefore, $k_{1}$ is considered to vary from $2.03 \times 10^{-31}$ to $2.2 \times 10^{-28} \mathrm{~cm}^{6} \mathrm{~s}^{-1}$ in theory, which well covered coefficients obtained in our experiments and reported in Beijing. ${ }^{21}$ It should be pointed out that in the real atmosphere, $k_{1}$ can vary over a larger range due to the complexity of sCI chemistry.

$k_{2}$ is also an apparent coefficient by considering the rate constant of the $\mathrm{OH}-\mathrm{SO}_{2}$ reaction $\left(k_{\mathrm{OH}-\mathrm{SO}_{2}}\right)$ and the preexponential coefficient ( $a$, see Table S5) of the $J\left(\mathrm{O}^{1} \mathrm{D}\right)-\mathrm{OH}$ nearly linear relationship, which can be described as $[\mathrm{OH}]=$ $\mathrm{a} \times J\left(\mathrm{O}^{1} \mathrm{D}\right) / 10^{-5} \mathrm{~s}^{-1} \cdot k_{\mathrm{OH}-\mathrm{SO}_{2}}$ was reported to be in the range from $3.39 \times 10^{-13}$ to $1.24 \times 10^{-12} \mathrm{~cm}^{3} \mathrm{~s}^{-1}, 55-58$ and the value of coefficient $a$ varied from $2 \times 10^{6}$ to $4.8 \times 10^{6} \mathrm{~cm}^{-3}$ in different observations (see Table S5). Therefore, the theoretical value of $k_{2}$ should range from 0.068 to 0.595 . Here, the fitted $k_{2}$ varied from 0.058 to 0.18 for the different seasons, mostly within the theoretical value range.

Although the fitted $k_{1}$ is within the theoretical range, calculations accordingly underestimated the nighttime $\mathrm{H}_{2} \mathrm{SO}_{4}$ significantly (Figure 4 and Figure S7) when the reaction of 


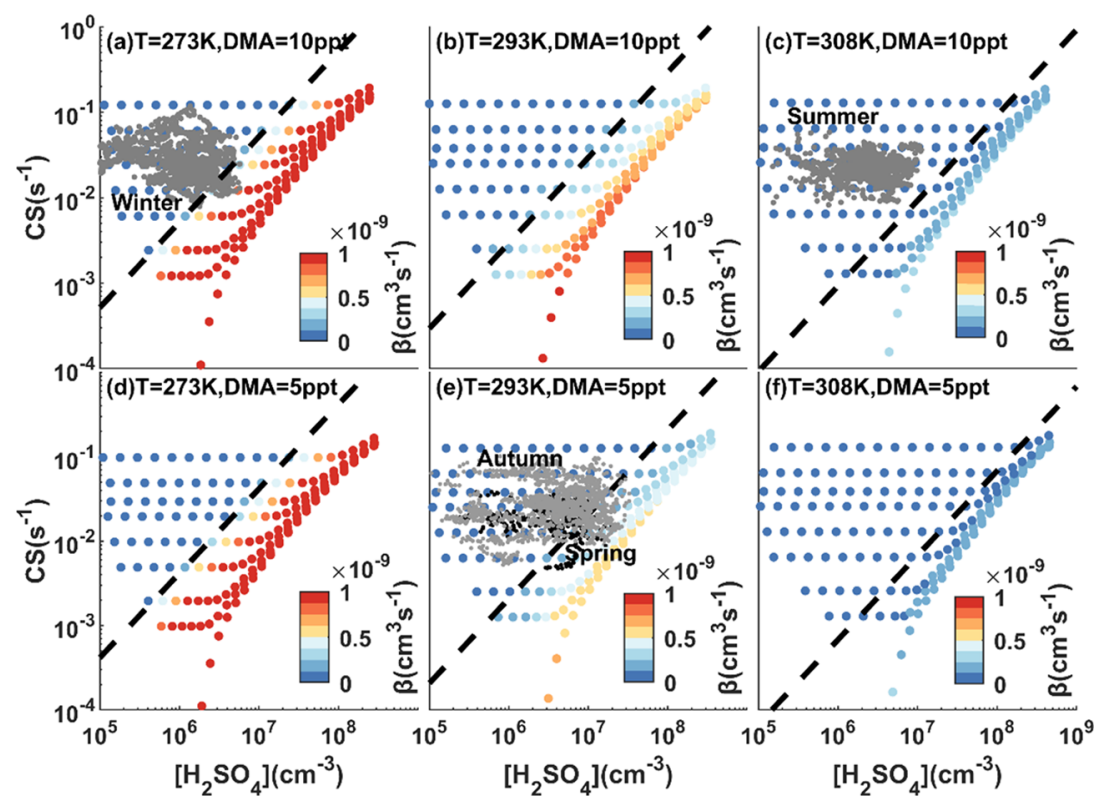

Figure 3. Dependences of $\beta$ on $\mathrm{H}_{2} \mathrm{SO}_{4}$ and CS with $10 \mathrm{ppt}$ of DMA at different temperatures $(\mathrm{a}-\mathrm{c})$ and 5 ppt of DMA at different temperatures $(\mathrm{d}-\mathrm{f})$. Gray dots denote daytime measurements during winter, summer, and autumn. Black dots denote daytime measurements during spring.

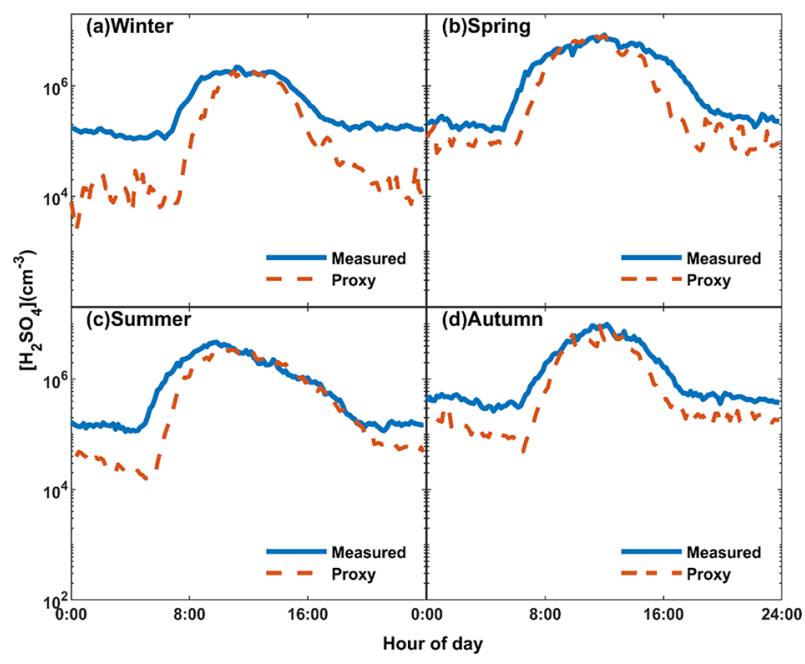

Figure 4. $(a-d)$ Diurnal variation of measured SA and simulated SA based on eq 6. Coefficients in four seasons are listed in Table S3.

$\mathrm{SO}_{2}$ with $\mathrm{sCI}$ or $\mathrm{OH}$ from ozonolysis of alkenes was assumed to be the major source. This is particularly the truth during winter when simulated $\mathrm{H}_{2} \mathrm{SO}_{4}$ was one order of magnitude lower than the measured value.

As shown in Figure 5a, the correlation between the loss of nighttime $\mathrm{H}_{2} \mathrm{SO}_{4}$ and $\left(\left[\mathrm{SO}_{2}\right]\left[\mathrm{O}_{3}\right]\right.$ [alkenes] $)$ is poor, indicating additional sources other than alkene ozonolysis contributing to the nighttime $\mathrm{H}_{2} \mathrm{SO}_{4}$. We then investigated nighttime $\mathrm{H}_{2} \mathrm{SO}_{4}$ events, defined by two criteria: (a) $\mathrm{H}_{2} \mathrm{SO}_{4}$ rises, reaching a distinct peak, instead of a continuous decrease from 20:00 to 04:00 in the following day; (b) the maximum concentration exceeds $1 \times 10^{6} \mathrm{~cm}^{-3}$. In total, 14 events were selected (Figure S8), only 3 of which can be explained by the source of alkene ozonolysis. However, in 6 events, the $\mathrm{H}_{2} \mathrm{SO}_{4}$ concentration correlated strongly with the benzene concentration (Figure S9), indicating a direct emission source related to benzene. Here, we used the toluene-to-benzene $(\mathrm{T} / \mathrm{B})$ ratio to indicate the sources of VOCs. The T/B in nighttime benzene-related
$\mathrm{H}_{2} \mathrm{SO}_{4}$ events has a range of $1-2$, very close to road-side and tunnel research studies. ${ }^{59,60} \mathrm{SO}_{2}$ is a byproduct of the combustion of most fossil fuels and has been reported to be emitted from on-road transportation. ${ }^{61}$ Since $\mathrm{OH}$ is also largely produced via burning processes, ${ }^{62} \mathrm{H}_{2} \mathrm{SO}_{4}$ is then able to be emitted from vehicles or produced in the freshly emitted plumes by reacting with ambient $\mathrm{SO}_{2}$.

To estimate the quantitative contribution from direct emissions, we selected the data points that cannot be explained by the alkene ozonolysis source, locating in the left of the line with $k_{1}=5 \times 10^{-29} \mathrm{~cm}^{6} \mathrm{~s}^{-1}$ in Figure $5 \mathrm{a}$. $\mathrm{O}_{3}$ concentrations for these data points were very low, probably due to a strong titration by freshly emitted NO. Because of the very short lifetime of gaseous $\mathrm{H}_{2} \mathrm{SO}_{4}$ in polluted air, plumes with freshly emitted $\mathrm{H}_{2} \mathrm{SO}_{4}$ need to transport quickly enough and have low pre-existing particle loading to overcome the loss of $\mathrm{H}_{2} \mathrm{SO}_{4}$ before arriving at the sampling site. Here, we separated the plumes using the wind speed threshold of $1.5 \mathrm{~m} / \mathrm{s}$ and $0.02 \mathrm{~s}^{-1}$ for CS. Under high wind speed and low condensation sink, a positive correlation between the $\mathrm{H}_{2} \mathrm{SO}_{4}$ and benzene concentrations was observed (Figure $5 \mathrm{~b}$ ), suggesting that direct emissions related to benzene play an important role in nighttime $\mathrm{H}_{2} \mathrm{SO}_{4}$ formation. However, we cannot observe the signal of direct emission at other times. As a matter of fact, the observed $\mathrm{H}_{2} \mathrm{SO}_{4}$ concentration from emission is governed by both the intensity of emissions and losses along the transmission path. Since this term was found to be related to benzene, we could assume the intensity of primary emissions to be proportional to the concentration of benzene. Also, with wind speed and condensation sink into consideration, the emission term of $\mathrm{H}_{2} \mathrm{SO}_{4}$ can be expressed as

$$
\left[\mathrm{H}_{2} \mathrm{SO}_{4}\right]_{\mathrm{emis}}=k_{0}[\text { benzene }]\left(\frac{\mathrm{WS}}{1 \mathrm{~m} \mathrm{~s}^{-1}}\right)^{a}\left(\frac{\mathrm{CS}}{0.01 \mathrm{~s}^{-1}}\right)^{b}
$$

Here, the pre-exponential coefficient, $k_{0}$, reflects the dependence on the intensity of emissions. The exponents $a$ and $b$ reflect the effects of wind speed and condensation sink, respectively. We further fitted these coefficients based on the 

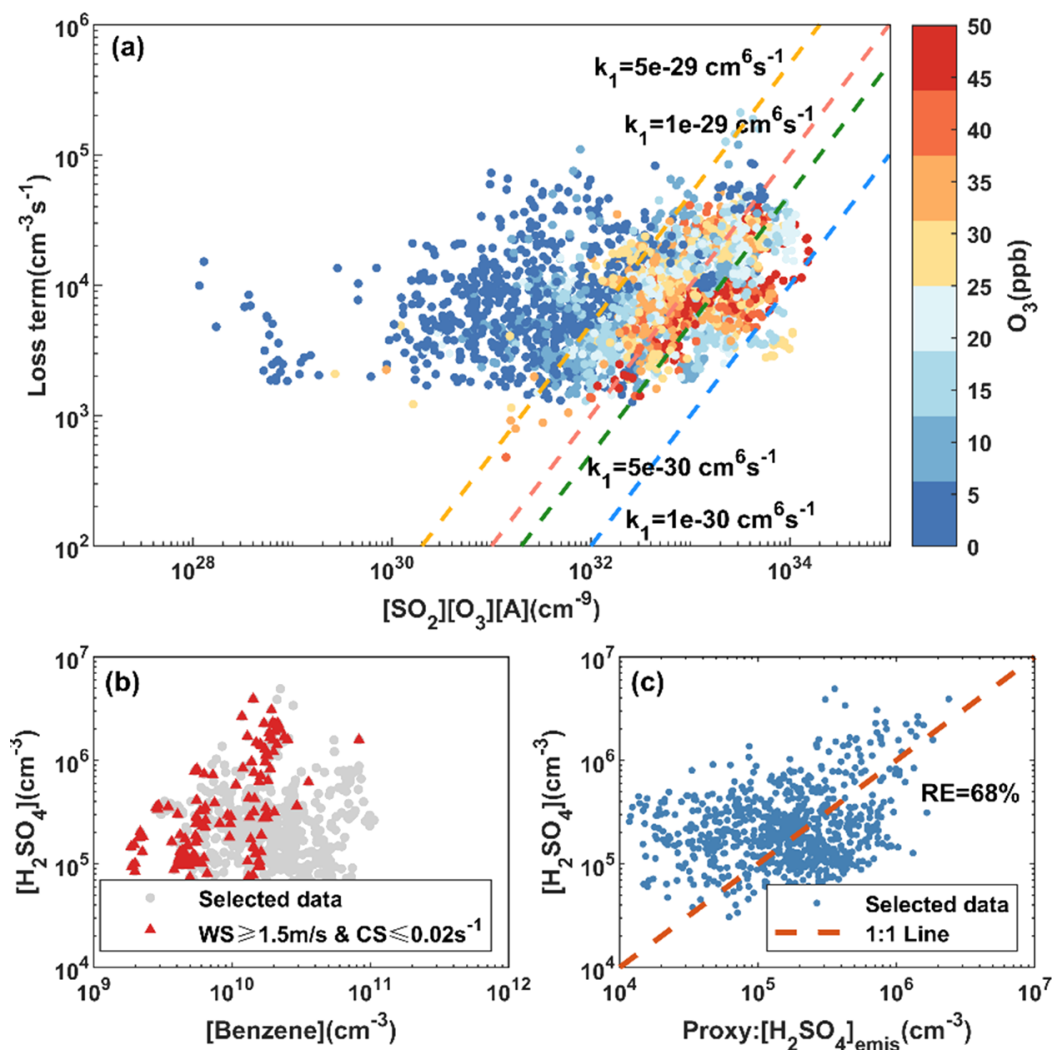

Figure 5. (a) Scatter plot of loss term $\left([\mathrm{SA}] \mathrm{CS}+[\mathrm{SA}] \mathrm{Dep}+\beta[\mathrm{SA}]^{2}\right)$ and the source term $\left(\left[\mathrm{SO}_{2}\right]\left[\mathrm{O}_{3}\right][\right.$ alkenes $\left.]\right)$. The data is colored with $\mathrm{O}_{3}$ concentration. (b) Scatter plot of benzene and unexplainable nighttime $\mathrm{H}_{2} \mathrm{SO}_{4}$. Gray dots denote all unexplainable nighttime $\mathrm{H}_{2} \mathrm{SO}_{4}$. Red triangles denote points with WS $\geq 1.5 \mathrm{~m} / \mathrm{s}$ and CS $\leq 0.02 \mathrm{~s}^{-1}$ and the correlation coefficient (Spearman type) is 0.563 . (c) Relationship between the nonlinear proxy of emissions and nighttime $\mathrm{H}_{2} \mathrm{SO}_{4}$ unexplained by the alkene ozonolysis source. The correlation coefficient (Pearson type) is 0.457 and the relative error is $68 \%$.

nighttime data that cannot be explained by the alkene ozonolysis source. The values of $k_{0}, a$, and $b$ were $2.591 \times$ $10^{-5}, 1.398$, and -1.404 , respectively. Figure $5 \mathrm{c}$ shows the good performance of the proxy; the simulated emission term was well correlated with the unexplainable nighttime $\mathrm{H}_{2} \mathrm{SO}_{4}$. It needs to be noted that the contribution of direct emission to the observed $\mathrm{H}_{2} \mathrm{SO}_{4}$ concentration should be site/locationdependent. Primary $\mathrm{H}_{2} \mathrm{SO}_{4}$ has the potential to be co-emitted with $\mathrm{SO}_{2}$ from power plants, industry, international ships, residential emissions, and transportation on a global scale. ${ }^{63}$ Parameters, including the distance of emission sources and meteorological conditions, would have significant impacts on this term.

Proxy Development and Its Stability. Based on the above budget analysis of $\mathrm{H}_{2} \mathrm{SO}_{4}$, we developed a physical proxy for $\mathrm{H}_{2} \mathrm{SO}_{4}$ as follows, by considering all the above-mentioned sources and sinks:

$$
\begin{aligned}
& {\left[\mathrm{H}_{2} \mathrm{SO}_{4}\right]=-\frac{\mathrm{CS}+\text { Dep }}{2 \beta}} \\
& +\sqrt{\left(\frac{\mathrm{CS}+\mathrm{Dep}}{2 \beta}\right)^{2}+\frac{k_{1}\left[\mathrm{SO}_{2}\right]\left[\mathrm{O}_{3}\right][\text { alkenes }]+k_{2} J\left(\mathrm{O}^{1} \mathrm{D}\right)\left[\mathrm{SO}_{2}\right]}{\beta}} \\
& +\left[\mathrm{H}_{2} \mathrm{SO}_{4}\right]_{\text {emis }}
\end{aligned}
$$

Here, $k_{1}$ is an apparent reaction rate constant, including the rate constant of the $\mathrm{O}_{3}$-alkenes reaction, the yield of $\mathrm{OH}$ radical and $\mathrm{sCI}$, and the fraction and rate constants of their reaction with $\mathrm{SO}_{2} ; k_{2}$ is also an apparent coefficient that takes into account the rate constant of the $\mathrm{OH}-\mathrm{SO}_{2}$ reaction and the pre-exponential coefficient of the nearly linear relationship between $J\left(\mathrm{O}^{1} \mathrm{D}\right)$ and $\mathrm{OH}$. We first selected nighttime data points with $\mathrm{O}_{3}$ concentrations higher than $10 \mathrm{ppb}$ in different seasons to obtain $k_{1}$. As shown in Figure S10, the loss term of nighttime $\mathrm{H}_{2} \mathrm{SO}_{4}$ was strongly and positively correlated with the source term $\left(\left[\mathrm{SO}_{2}\right]\left[\mathrm{O}_{3}\right][\right.$ alkenes $\left.]\right)$ at high concentrations of $\mathrm{O}_{3}$, suggesting that the alkene ozonolysis contributed significantly to the nighttime $\mathrm{H}_{2} \mathrm{SO}_{4}$ concentration. We then estimated $k_{1}$ by fitting the 10 th percentile data points to eliminate the impact of emissions to the extent possible. The estimated value of $k_{1}$ ranged from $6.67 \times 10^{-31}$ to $5.27 \times 10^{-30}$ $\mathrm{cm}^{6} \mathrm{~s}^{-1}$ in different seasons, within the range of the theoretical value. The fitted $k_{2}$ varied from 0.08 to 0.18 in different seasons (see Table S4), also within the range of the theoretical value.

The developed proxies captured well the measured values in different seasons (Figure S12a-d) and surprisingly correlated with each other very well (Figure S13), with correlation coefficients larger than 0.94, suggesting the strong stability of this method and the possibility to develop a more widely used proxy based on the data from all the seasons. The fitted values of $k_{1}$ and $k_{2}$ were $2.49 \times 10^{-30} \mathrm{~cm}^{6} \mathrm{~s}^{-1}$ and 0.15 , respectively, so the proxy can be written as

$$
\begin{aligned}
& {\left[\mathrm{H}_{2} \mathrm{SO}_{4}\right]=-\frac{\mathrm{CS}+\mathrm{Dep}}{2 \beta}} \\
& +\sqrt{\left(\frac{\mathrm{CS}+\mathrm{Dep}}{2 \beta}\right)^{2}+\frac{2.49 \times 10^{-30}\left[\mathrm{O}_{3}\right][\text { alkenes }]\left[\mathrm{SO}_{2}\right]+0.15 J\left(\mathrm{O}^{1} \mathrm{D}\right)\left[\mathrm{SO}_{2}\right]}{\beta}} \\
& +\left[\mathrm{H}_{2} \mathrm{SO}_{4}\right]_{\text {emis }}
\end{aligned}
$$



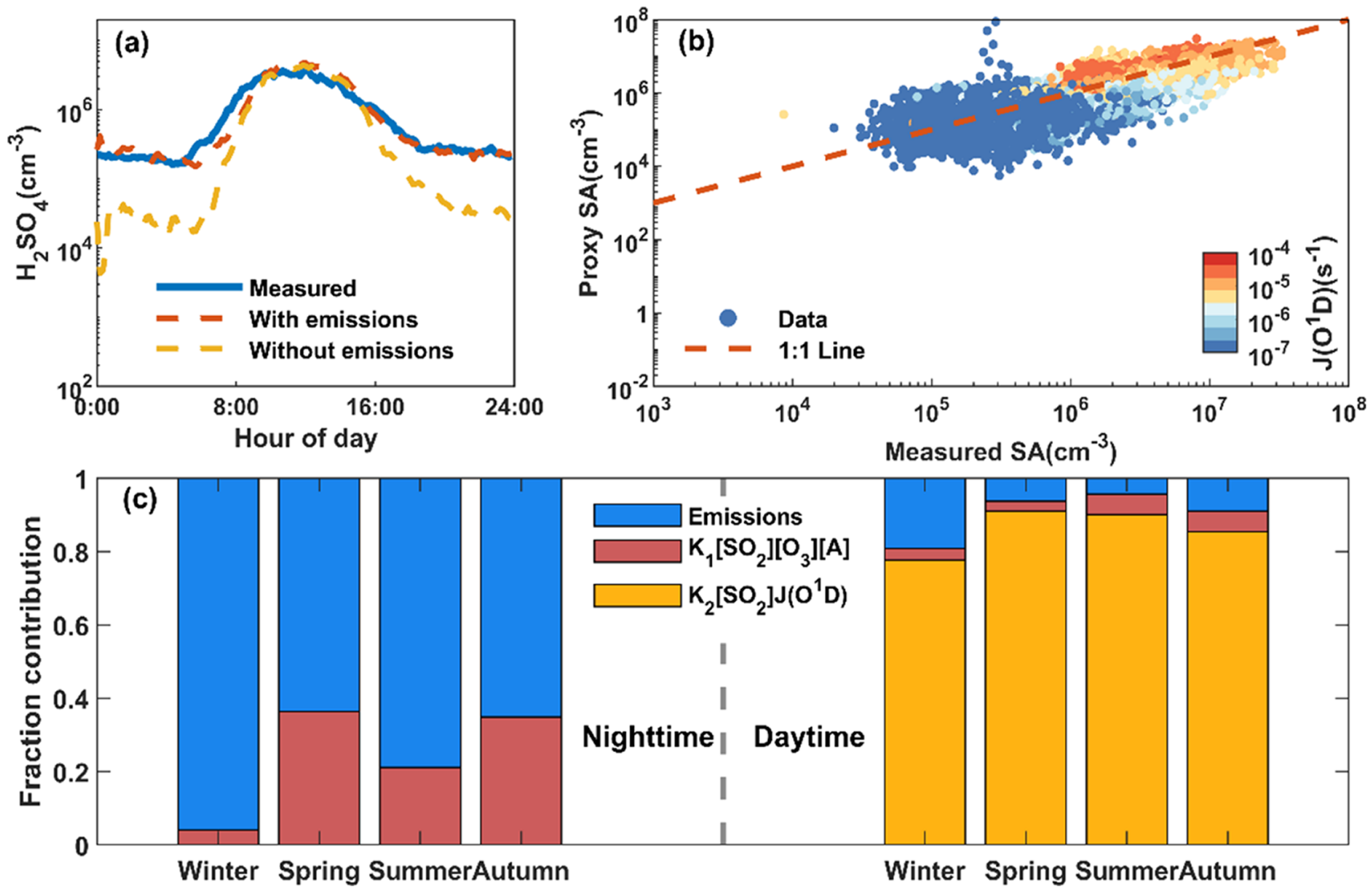

Figure 6. $\mathrm{H}_{2} \mathrm{SO}_{4}$ proxy based on data points during the total period (eq 9). (a) Diurnal variation of $\mathrm{H}_{2} \mathrm{SO}_{4}$ proxy and measured concentrations; (b) relationship between proxy $\mathrm{H}_{2} \mathrm{SO}_{4}$ and measured $\mathrm{H}_{2} \mathrm{SO}_{4}$; (c) fraction contribution of each source term to $\mathrm{H}_{2} \mathrm{SO}_{4}$ concentration during the nighttime and daytime.

This final proxy showed a good performance in such a complex environment (Figure 6a), the simulated values being very close to the measured ones (Figure $6 a, b$ ), with a relative error of $58 \%$ and the correlation coefficient of 0.71 . Given the systematic uncertainty in $\mathrm{H}_{2} \mathrm{SO}_{4}$ concentration discussed in the method part, our results suggest a nearly close relationship between measurements and proxy. In particular, the simulation of $\mathrm{H}_{2} \mathrm{SO}_{4}$ in the nighttime and early morning was significantly improved with the consideration of direct emission. Meanwhile, due to negligible clustering processes at most times, the proxy involving the dominant influencing factor can be simplified as eq 10 .

$$
\begin{aligned}
{\left[\mathrm{H}_{2} \mathrm{SO}_{4}\right]=} & \frac{k_{1}\left[\mathrm{O}_{3}\right][\text { alkenes }]\left[\mathrm{SO}_{2}\right]+k_{2} J\left(\mathrm{O}^{1} \mathrm{D}\right)\left[\mathrm{SO}_{2}\right]}{\mathrm{CS}+\mathrm{Dep}} \\
& +\left[\mathrm{H}_{2} \mathrm{SO}_{4}\right]_{\text {emis }}
\end{aligned}
$$

We finally investigated the contribution from different sources quantitatively in different seasons based on the newly developed proxy (Figure 6c). As expected, the oxidation of $\mathrm{SO}_{2}$ by $\mathrm{OH}$ dominated the daytime $\mathrm{H}_{2} \mathrm{SO}_{4}$ formation with a contribution larger than $75 \%$ in all the seasons. Therefore, there is a possibility to derive a proxy based on the lightdependent source in the absence of more data. Ozonolysis of alkenes gave a small, about $6 \%$ contribution in both summer and autumn and smaller than $4 \%$ contribution in winter and spring. In winter daytime, primary emissions contributed considerably by more than $10 \%$. During the nighttime, direct emission contributed much more than alkene ozonolysis, up to more than $90 \%$ during winter and about $80 \%$ during summer.
Uncertainty Analysis. Here, we discussed the uncertainty of the final proxy. For the light-dependent source, the uncertainty of $\mathrm{OH}$ calculation consists of two main components: calculation of $J\left(\mathrm{O}^{1} \mathrm{D}\right)$ using the TUV radiation model and the precision of $\mathrm{OH}$ calculation based on $J\left(\mathrm{O}^{1} \mathrm{D}\right)$. The relative error between the modeled and measured $J\left(\mathrm{O}^{1} \mathrm{D}\right)$ was estimated to be within $10 \%$, except for the dust event days. ${ }^{64}$ Here, we corrected the calculated $J\left(\mathrm{O}^{1} \mathrm{D}\right)$ by the observed UVB to further lower the uncertainty, assuming 5\% (the uncertainty of UVB measurement). Also, the precision of the $J\left(\mathrm{O}^{1} \mathrm{D}\right)$ calculation of $\mathrm{OH}$ was reported to be $7.8 \%{ }^{41}$ Therefore, the total uncertainty of $\mathrm{OH}$ estimation should be around 9\% (calculated from $\sqrt{(5 \%)^{2}+(7.8 \%)^{2}}$ ). For the alkenes ozonolysis source, the uncertainty mainly comes from the estimation of total alkenes. First, relative precisions of measurements are $12 \%$ for isoprene and $10 \%$ for benzene. ${ }^{65}$ Second, the proxy of anthropogenic alkene causes a relative error of $28 \%$. The relative error of the emission term was estimated as $68 \%$ (Figure $5 \mathrm{c}$ ).

The CS was underestimated by about $8 \%$ because we used the particle size distribution from 6 to $800 \mathrm{~nm}$ instead of a full range (Figure S3). In the dry deposition model, the extremely high Henry's law coefficient of $\mathrm{H}_{2} \mathrm{SO}_{4}$ causes surface resistance, relying heavily on empirical data, which is negligible compared with aerodynamic and quasi-laminar resistance. However, the performance of the large-scale deposition model applied to such local measurements is not clear, ${ }^{38}$ and the uncertainty of dry deposition was assumed to be $100 \%$. Direct 
measurement of dry deposition is encouraged in the future to compare with the model-based estimation.

Environmental Implication. Gaseous sulfuric acid $\left(\mathrm{H}_{2} \mathrm{SO}_{4}\right)$ is essential for new particle formation (NPF) and therefore for the global budget of aerosol particles and cloud condensation nuclei. In situ measurements of $\mathrm{H}_{2} \mathrm{SO}_{4}$ are very rare, largely limiting our understanding of global NPF mechanisms. Previous efforts on building empirical proxies for $\mathrm{H}_{2} \mathrm{SO}_{4}$ have been demonstrated to be not broadly applicable. A physical proxy was believed to have a wide application, e.g., rebuild the long-term variation of $\mathrm{H}_{2} \mathrm{SO}_{4}$ in various environments. The detailed budget analysis of $\mathrm{H}_{2} \mathrm{SO}_{4}$ can shed some insights into improving the simulation of $\mathrm{H}_{2} \mathrm{SO}_{4}$, and nanoparticles, in the current regional and global air quality models that can help improve the global understanding of new particle and aerosol sulfate formation. In addition, a considerable contribution of primary emissions to $\mathrm{H}_{2} \mathrm{SO}_{4}$ indicates a new connection between human activities and climate change through anthropogenic $\mathrm{H}_{2} \mathrm{SO}_{4}$-induced secondary aerosol formation.

\section{ASSOCIATED CONTENT}

\section{SI Supporting Information}

The Supporting Information is available free of charge at https://pubs.acs.org/doi/10.1021/acs.est.1c00738.

Detailed descriptions of measurements of $\mathrm{H}_{2} \mathrm{SO}_{4}$, estimation of the hydroxyl radical, calculation of condensation sink, and dry deposition; map of the measurement of site (Figure $\mathrm{S} 1$ ); time series of $\mathrm{H}_{2} \mathrm{SO}_{4}$ and related parameters in four seasons (Figure S2); relationship between dominating alkenes and benzene (Figure S3); correlation between CS contributed by 6$800 \mathrm{~nm}$ particles and CS contributed by $4-19,800 \mathrm{~nm}$ particles (Figure S4); relationship between $\mathrm{H}_{2} \mathrm{SO}_{4}$ estimated by different proxies based on the empirical formulas in different seasons (Figure S5); comparison between daytime data in four seasons and simulations under different temperatures and DMA concentrations (Figure S6); performance of physical proxy without an emission term (Figure S7); time series of measured $\mathrm{H}_{2} \mathrm{SO}_{4}$, simulated $\mathrm{H}_{2} \mathrm{SO}_{4}$, and benzene during selected nighttime $\mathrm{H}_{2} \mathrm{SO}_{4}$ events (Figure $\mathrm{S} 8$ ); relationship between $\mathrm{H}_{2} \mathrm{SO}_{4}$ and benzene in emission cases (Figure S9); development of proxy with an emission term for four seasons (Figures $\mathrm{S} 10$ and $\mathrm{S} 11$ ); diurnal variations of measured $\mathrm{H}_{2} \mathrm{SO}_{4}$ and $\mathrm{H}_{2} \mathrm{SO}_{4}$ obtained from the respective steady-state equilibrium method with emissions into consideration (Figure S12); correlation between $\mathrm{H}_{2} \mathrm{SO}_{4}$ estimated by physical proxies in different seasons (Figure S13); development of the final proxy (Figure S14); results of the nonlinear proxy in daytime and comparison with previous works (Table S1); relative errors of traditional proxies (Table S2); coefficients of the physical proxy without an emission term (Table S3); coefficients of proxy based on seasonal data with $\mathrm{O}_{3} \geq 10 \mathrm{ppb}$ (Table S4); summary of the coefficients of the $\mathrm{OH}-J\left(\mathrm{O}^{1} \mathrm{D}\right)$ nearly linear relationship in observations (Table S5) (PDF)

\section{AUTHOR INFORMATION}

\section{Corresponding Author}

Wei Nie - Joint International Research Laboratory of Atmospheric and Earth System Sciences, School of Atmospheric Sciences, Nanjing University, Nanjing 210023, China; Jiangsu Provincial Collaborative Innovation Center of Climate Change, Nanjing 210023, China; 이이.org/ 0000-0002-6048-0515; Email: niewei@nju.edu.cn

\section{Authors}

Liwen Yang - Joint International Research Laboratory of Atmospheric and Earth System Sciences, School of Atmospheric Sciences, Nanjing University, Nanjing 210023, China; Jiangsu Provincial Collaborative Innovation Center of Climate Change, Nanjing 210023, China

Yuliang Liu - Joint International Research Laboratory of Atmospheric and Earth System Sciences, School of Atmospheric Sciences, Nanjing University, Nanjing 210023, China; Jiangsu Provincial Collaborative Innovation Center of Climate Change, Nanjing 210023, China

Zhengning Xu - Joint International Research Laboratory of Atmospheric and Earth System Sciences, School of Atmospheric Sciences, Nanjing University, Nanjing 210023, China; Jiangsu Provincial Collaborative Innovation Center of Climate Change, Nanjing 210023, China

Mao Xiao - Laboratory of Atmospheric Chemistry, Paul Scherrer Institute, 5232 Villigen, Switzerland

Ximeng Qi - Joint International Research Laboratory of Atmospheric and Earth System Sciences, School of Atmospheric Sciences, Nanjing University, Nanjing 210023, China; Jiangsu Provincial Collaborative Innovation Center of Climate Change, Nanjing 210023, China

Yuanyuan Li - Joint International Research Laboratory of Atmospheric and Earth System Sciences, School of Atmospheric Sciences, Nanjing University, Nanjing 210023, China; Jiangsu Provincial Collaborative Innovation Center of Climate Change, Nanjing 210023, China

Ruoxian Wang - Joint International Research Laboratory of Atmospheric and Earth System Sciences, School of Atmospheric Sciences, Nanjing University, Nanjing 210023, China; Jiangsu Provincial Collaborative Innovation Center of Climate Change, Nanjing 210023, China

Jun Zou - Joint International Research Laboratory of Atmospheric and Earth System Sciences, School of Atmospheric Sciences, Nanjing University, Nanjing 210023, China; Jiangsu Provincial Collaborative Innovation Center of Climate Change, Nanjing 210023, China

Pauli Paasonen - Institute for Atmospheric and Earth System Research/Physics, Faculty of Science, University of Helsinki, 00014 Helsinki, Finland

Chao Yan - Institute for Atmospheric and Earth System Research/Physics, Faculty of Science, University of Helsinki, 00014 Helsinki, Finland

Zheng Xu - Joint International Research Laboratory of Atmospheric and Earth System Sciences, School of Atmospheric Sciences, Nanjing University, Nanjing 210023, China; Jiangsu Provincial Collaborative Innovation Center of Climate Change, Nanjing 210023, China

Jiaping Wang - Joint International Research Laboratory of Atmospheric and Earth System Sciences, School of Atmospheric Sciences, Nanjing University, Nanjing 210023, China; Jiangsu Provincial Collaborative Innovation Center of Climate Change, Nanjing 210023, China 
Chen Zhou - Joint International Research Laboratory of Atmospheric and Earth System Sciences, School of Atmospheric Sciences, Nanjing University, Nanjing 210023, China; Jiangsu Provincial Collaborative Innovation Center of Climate Change, Nanjing 210023, China

Jian Yuan - Joint International Research Laboratory of Atmospheric and Earth System Sciences, School of Atmospheric Sciences, Nanjing University, Nanjing 210023, China; Jiangsu Provincial Collaborative Innovation Center of Climate Change, Nanjing 210023, China

Jianning Sun - Joint International Research Laboratory of Atmospheric and Earth System Sciences, School of Atmospheric Sciences, Nanjing University, Nanjing 210023, China; Jiangsu Provincial Collaborative Innovation Center of Climate Change, Nanjing 210023, China

Xuguang Chi - Joint International Research Laboratory of Atmospheric and Earth System Sciences, School of Atmospheric Sciences, Nanjing University, Nanjing 210023, China; Jiangsu Provincial Collaborative Innovation Center of Climate Change, Nanjing 210023, China

Veli-Matti Kerminen - Joint International Research Laboratory of Atmospheric and Earth System Sciences, School of Atmospheric Sciences, Nanjing University, Nanjing 210023, China; Institute for Atmospheric and Earth System Research/Physics, Faculty of Science, University of Helsinki, 00014 Helsinki, Finland

Markku Kulmala - Joint International Research Laboratory of Atmospheric and Earth System Sciences, School of Atmospheric Sciences, Nanjing University, Nanjing 210023, China; Institute for Atmospheric and Earth System Research/ Physics, Faculty of Science, University of Helsinki, 00014 Helsinki, Finland

Aijun Ding - Joint International Research Laboratory of Atmospheric and Earth System Sciences, School of Atmospheric Sciences, Nanjing University, Nanjing 210023, China; Jiangsu Provincial Collaborative Innovation Center of Climate Change, Nanjing 210023, China

Complete contact information is available at: https://pubs.acs.org/10.1021/acs.est.1c00738

\section{Notes}

The authors declare no competing financial interest.

\section{ACKNOWLEDGMENTS}

This work was mainly funded by the National Key R\&D Program of China (2016YFC0202000 and 2016YFC0200500) and the National Natural Science Foundation of China (NSFC) project (41675145 and 91644218). Data analysis was also supported by other NSFC projects (41875175, 41605098, 42075101, 41875004, and 92044301), Jiangsu Province Key R\&D Program Major Technology Demonstration (BE 2019704), Academy of Finland via Center of Excellence in Atmospheric Sciences (project no. 307331), and European Research Council via ATM-GTP (742206).

\section{REFERENCES}

(1) Huang, R.-J.; Zhang, Y.; Bozzetti, C.; Ho, K.-F.; Cao, J.-J.; Han, Y.; Daellenbach, K. R.; Slowik, J. G.; Platt, S. M.; Canonaco, F.; Zotter, P.; Wolf, R.; Pieber, S. M.; Bruns, E. A.; Crippa, M.; Ciarelli, G.; Piazzalunga, A.; Schwikowski, M.; Abbaszade, G.; Schnelle-Kreis, J.; Zimmermann, R.; An, Z.; Szidat, S.; Baltensperger, U.; El Haddad, I.; Prévôt, A. S. H. High secondary aerosol contribution to particulate pollution during haze events in China. Nature 2014, 514, 218-222.
(2) Chow, J. C.; Watson, J. G.; Mauderly, J. L.; Costa, D. L.; Wyzga, R. E.; Vedal, S.; Hidy, G. M.; Altshuler, S. L.; Marrack, D.; Heuss, J. M.; Wolff, G. T.; Arden Pope, C., III; Dockery, D. W. Health effects of fine particulate air pollution: Lines that connect. J. Air Waste Manage. Assoc. 2006, 56, 1368-1380.

(3) Charlson, R. J.; Schwartz, S. E.; Hales, J. M.; Cess, R. D.; Coakley, J. A.; Hansen, J. E.; Hofmann, D. J. Climate Forcing by Anthropogenic Aerosols. Science 1992, 255, 423-430.

(4) Kerminen, V.-M.; Chen, X.; Vakkari, V.; Petäjä, T.; Kulmala, M.; Bianchi, F. Atmospheric new particle formation and growth: review of field observations. Environ. Res. Lett. 2018, 13, 103003.

(5) Yue, D.; Hu, M.; Wu, Z.; Wang, Z.; Guo, S.; Wehner, B.; Nowak, A.; Achtert, P.; Wiedensohler, A.; Jung, J.; Kim, Y. J.; Liu, S. Characteristics of aerosol size distributions and new particle formation in the summer in Beijing. J. Geophys. Res.: Atmos. 2009, 114, 13.

(6) Ball, S. M.; Hanson, D. R.; Eisele, F. L.; McMurry, P. H. Laboratory studies of particle nucleation: Initial results for $\mathrm{H}_{2} \mathrm{SO}_{4}$, $\mathrm{H}_{2} \mathrm{O}$, and $\mathrm{NH}_{3}$ vapors. J. Geophys. Res.: Atmos. 1999, 104, 2370923718.

(7) Kirkby, J.; Curtius, J.; Almeida, J.; Dunne, E.; Duplissy, J.; Ehrhart, S.; Franchin, A.; Gagné, S.; Ickes, L.; Kürten, A.; Kupc, A.; Metzger, A.; Riccobono, F.; Rondo, L.; Schobesberger, S.; Tsagkogeorgas, G.; Wimmer, D.; Amorim, A.; Bianchi, F.; Breitenlechner, M.; David, A.; Dommen, J.; Downard, A.; Ehn, M.; Flagan, R. C.; Haider, S.; Hansel, A.; Hauser, D.; Jud, W.; Junninen, H.; Kreissl, F.; Kvashin, A.; Laaksonen, A.; Lehtipalo, K.; Lima, J.; Lovejoy, E. R.; Makhmutov, V.; Mathot, S.; Mikkilä, J.; Minginette, P.; Mogo, S.; Nieminen, T.; Onnela, A.; Pereira, P.; Petäjä, T.; Schnitzhofer, R.; Seinfeld, J. H.; Sipilä, M.; Stozhkov, Y.; Stratmann, F.; Tomé, A.; Vanhanen, J.; Viisanen, Y.; Vrtala, A.; Wagner, P. E.; Walther, H.; Weingartner, E.; Wex, H.; Winkler, P. M.; Carslaw, K. S.; Worsnop, D. R.; Baltensperger, U.; Kulmala, M. Role of sulphuric acid, ammonia and galactic cosmic rays in atmospheric aerosol nucleation. Nature 2011, 476, 429-433.

(8) Yao, L.; Garmash, O.; Bianchi, F.; Zheng, J.; Yan, C.; Kontkanen, J.; Junninen, H.; Mazon, S. B.; Ehn, M.; Paasonen, P.; Sipilä, M.; Wang, M.; Wang, X.; Xiao, S.; Chen, H.; Lu, Y.; Zhang, B.; Wang, D.; Fu, Q.; Geng, F.; Li, L.; Wang, H.; Qiao, L.; Yang, X.; Chen, J.; Kerminen, V. M.; Petäjä, T.; Worsnop, D. R.; Kulmala, M.; Wang, L. Atmospheric new particle formation from sulfuric acid and amines in a Chinese megacity. Science 2018, 361, 278-281.

(9) Almeida, J.; Schobesberger, S.; Kürten, A.; Ortega, I. K.; Kupiainen-Määttä, O.; Praplan, A. P.; Adamov, A.; Amorim, A.; Bianchi, F.; Breitenlechner, M.; David, A.; Dommen, J.; Donahue, N. M.; Downard, A.; Dunne, E.; Duplissy, J.; Ehrhart, S.; Flagan, R. C.; Franchin, A.; Guida, R.; Hakala, J.; Hansel, A.; Heinritzi, M.; Henschel, H.; Jokinen, T.; Junninen, H.; Kajos, M.; Kangasluoma, J.; Keskinen, H.; Kupc, A.; Kurtén, T.; Kvashin, A. N.; Laaksonen, A.; Lehtipalo, K.; Leiminger, M.; Leppä, J.; Loukonen, V.; Makhmutov, V.; Mathot, S.; McGrath, M. J.; Nieminen, T.; Olenius, T.; Onnela, A.; Petäjä, T.; Riccobono, F.; Riipinen, I.; Rissanen, M.; Rondo, L.; Ruuskanen, T.; Santos, F. D.; Sarnela, N.; Schallhart, S.; Schnitzhofer, R.; Seinfeld, J. H.; Simon, M.; Sipilä, M.; Stozhkov, Y.; Stratmann, F.; Tomé, A.; Tröstl, J.; Tsagkogeorgas, G.; Vaattovaara, P.; Viisanen, Y.; Virtanen, A.; Vrtala, A.; Wagner, P. E.; Weingartner, E.; Wex, H.; Williamson, C.; Wimmer, D.; Ye, P.; Yli-Juuti, T.; Carslaw, K. S.; Kulmala, M.; Curtius, J.; Baltensperger, U.; Worsnop, D. R.; Vehkamäki, H.; Kirkby, J. Molecular understanding of sulphuric acid-amine particle nucleation in the atmosphere. Nature 2013, 502, 359-363.

(10) Zhang, R.; Suh, I.; Zhao, J.; Zhang, D.; Fortner, E. C.; Tie, X.; Molina, L. T.; Molina, M. J. Atmospheric new particle formation enhanced by organic acids. Science 2004, 304, 1487-1490.

(11) Riccobono, F.; Schobesberger, S.; Scott, C. E.; Dommen, J.; Ortega, I. K.; Rondo, L.; Almeida, J.; Amorim, A.; Bianchi, F.; Breitenlechner, M.; David, A.; Downard, A.; Dunne, E. M.; Duplissy, J.; Ehrhart, S.; Flagan, R. C.; Franchin, A.; Hansel, A.; Junninen, H.; Kajos, M.; Keskinen, H.; Kupc, A.; Kurten, A.; Kvashin, A. N.; Laaksonen, A.; Lehtipalo, K.; Makhmutov, V.; Mathot, S.; Nieminen, 
T.; Onnela, A.; Petaja, T.; Praplan, A. P.; Santos, F. D.; Schallhart, S.; Seinfeld, J. H.; Sipila, M.; Spracklen, D. V.; Stozhkov, Y.; Stratmann, F.; Tome, A.; Tsagkogeorgas, G.; Vaattovaara, P.; Viisanen, Y.; Vrtala, A.; Wagner, P. E.; Weingartner, E.; Wex, H.; Wimmer, D.; Carslaw, K. S.; Curtius, J.; Donahue, N. M.; Kirkby, J.; Kulmala, M.; Worsnop, D. R.; Baltensperger, U. Oxidation Products of Biogenic Emissions Contribute to Nucleation of Atmospheric Particles. Science 2014, 344, 717-721.

(12) Lehtipalo, K.; Yan, C.; Dada, L.; Bianchi, F.; Xiao, M.; Wagner, R.; Stolzenburg, D.; Ahonen, L. R.; Amorim, A.; Baccarini, A.; Bauer, P. S.; Baumgartner, B.; Bergen, A.; Bernhammer, A. K.; Breitenlechner, M.; Brilke, S.; Buchholz, A.; Mazon, S. B.; Chen, D.; Chen, X.; Dias, A.; Dommen, J.; Draper, D. C.; Duplissy, J.; Ehn, M.; Finkenzeller, H.; Fischer, L.; Frege, C.; Fuchs, C.; Garmash, O.; Gordon, H.; Hakala, J.; He, X.; Heikkinen, L.; Heinritzi, M.; Helm, J. C.; Hofbauer, V.; Hoyle, C. R.; Jokinen, T.; Kangasluoma, J.; Kerminen, V. M.; Kim, C.; Kirkby, J.; Kontkanen, J.; Kürten, A.; Lawler, M. J.; Mai, H.; Mathot, S.; Mauldin, R. L., III; Molteni, U.; Nichman, L.; Nie, W.; Nieminen, T.; Ojdanic, A.; Onnela, A.; Passananti, M.; Petäjä, T.; Piel, F.; Pospisilova, V.; Quéléver, L. L. J.; Rissanen, M. P.; Rose, C.; Sarnela, N.; Schallhart, S.; Schuchmann, S.; Sengupta, K.; Simon, M.; Sipilä, M.; Tauber, C.; Tomé, A.; Tröstl, J.; Väisänen, O.; Vogel, A. L.; Volkamer, R.; Wagner, A. C.; Wang, M.; Weitz, L.; Wimmer, D.; Ye, P.; Ylisirniö, A.; Zha, Q.; Carslaw, K. S.; Curtius, J.; Donahue, N. M.; Flagan, R. C.; Hansel, A.; Riipinen, I.; Virtanen, A.; Winkler, P. M.; Baltensperger, U.; Kulmala, M.; Worsnop, D. R. Multicomponent new particle formation from sulfuric acid, ammonia, and biogenic vapors. Sci. Adv. 2018, 4, eaau5363.

(13) Birmili, W.; Berresheim, H.; Plass-Dülmer, C.; Elste, T.; Gilge, S.; Wiedensohler, A.; Uhrner, U. The Hohenpeissenberg aerosol formation experiment (HAFEX): a long-term study including sizeresolved aerosol, $\mathrm{H}_{2} \mathrm{SO}_{4}, \mathrm{OH}$, and monoterpenes measurements. Atmos. Chem. Phys. 2003, 3, 361-376.

(14) Erupe, M. E.; Benson, D. R.; Li, J.; Young, L.-H.; Verheggen, B.; al-Refai, M.; Tahboub, O.; Cunningham, V.; Frimpong, F.; Viggiano, A. A.; Lee, S.-H. Correlation of aerosol nucleation rate with sulfuric acid and ammonia in Kent, Ohio: An atmospheric observation. J. Geophys. Res.: Atmos. 2010, 115, 18.

(15) Riipinen, I.; Sihto, S.-L.; Kulmala, M.; Arnold, F.; Dal Maso, M.; Birmili, W.; Saarnio, K.; Teinilä, K.; Kerminen, V.-M.; Laaksonen, A.; Lehtinen, K. E. J. Connections between atmospheric sulphuric acid and new particle formation during QUEST III-IV campaigns in Heidelberg and Hyytiälä. Atmos. Chem. Phys. 2007, 7, 1899-1914.

(16) Mikkonen, S.; Romakkaniemi, S.; Smith, J. N.; Korhonen, H.; Petäjä, T.; Plass-Duelmer, C.; Boy, M.; McMurry, P. H.; Lehtinen, K. E. J.; Joutsensaari, J.; Hamed, A.; Mauldin Iii, R. L.; Birmili, W.; Spindler, G.; Arnold, F.; Kulmala, M.; Laaksonen, A. A statistical proxy for sulphuric acid concentration. Atmos. Chem. Phys. 2011, 11, 11319-11334.

(17) Berresheim, H.; Adam, M.; Monahan, C.; O’Dowd, C.; Plane, J. M. C.; Bohn, B.; Rohrer, F. Missing $\mathrm{SO}_{2}$ oxidant in the coastal atmosphere? - observations from high-resolution measurements of $\mathrm{OH}$ and atmospheric sulfur compounds. Atmos. Chem. Phys. 2014, 14, 12209-12223.

(18) Dada, L.; Ylivinkka, I.; Baalbaki, R.; Li, C.; Guo, Y.; Yan, C.; Yao, L.; Sarnela, N.; Jokinen, T.; Daellenbach, K. R.; Yin, R.; Deng, C.; Chu, B.; Nieminen, T.; Wang, Y.; Lin, Z.; Thakur, R. C.; Kontkanen, J.; Stolzenburg, D.; Sipilä, M.; Hussein, T.; Paasonen, P.; Bianchi, F.; Salma, I.; Weidinger, T.; Pikridas, M.; Sciare, J.; Jiang, J.; Liu, Y.; Petäjä, T.; Kerminen, V. M.; Kulmala, M. Sources and sinks driving sulfuric acid concentrations in contrasting environments: implications on proxy calculations. Atmos. Chem. Phys. 2020, 20, 11747-11766.

(19) Mauldin Iii, R. L.; Berndt, T.; Sipilä, M.; Paasonen, P.; Petäjä, T.; Kim, S.; Kurtén, T.; Stratmann, F.; Kerminen, V. M.; Kulmala, M. A new atmospherically relevant oxidant of sulphur dioxide. Nature 2012, 488, 193-196.

(20) Kim, S.; Guenther, A.; Lefer, B.; Flynn, J.; Griffin, R.; Rutter, A. P.; Gong, L.; Cevik, B. K. Potential Role of Stabilized Criegee Radicals in Sulfuric Acid Production in a High Biogenic VOC Environment. Environ. Sci. Technol. 2015, 49, 3383-3391.

(21) Guo, Y.; Yan, C.; Li, C.; Ma, W.; Feng, Z.; Zhou, Y.; Lin, Z.; Dada, L.; Stolzenburg, D.; Yin, R.; Kontkanen, J.; Daellenbach, K. R.; Kangasluoma, J.; Yao, L.; Chu, B.; Wang, Y.; Cai, R.; Bianchi, F.; Liu, Y.; Kulmala, M. Formation of nighttime sulfuric acid from the ozonolysis of alkenes in Beijing. Atmos. Chem. Phys. 2021, 21, 54995511.

(22) Berresheim, H.; Elste, T.; Tremmel, H. G.; Allen, A. G.; Hansson, H.-C.; Rosman, K.; Dal Maso, M.; Mäkelä, J. M.; Kulmala, M.; O'Dowd, C. D. Gas-aerosol relationships of $\mathrm{H}_{2} \mathrm{SO}_{4}, \mathrm{MSA}$, and $\mathrm{OH}$ : Observations in the coastal marine boundary layer at Mace Head, Ireland. J. Geophys. Res.: Atmos. 2002, 107, PAR5-1-PAR 5-12.

(23) Davis, D.; Chen, G.; Kasibhatla, P.; Jefferson, A.; Tanner, D.; Eisele, F.; Lenschow, D.; Neff, W.; Berresheim, H. DMS oxidation in the Antarctic marine boundary layer: Comparison of model simulations and field observations of DMS, DMSO, $\mathrm{DMSO}_{2}$, $\mathrm{H}_{2} \mathrm{SO}_{4}(\mathrm{~g}), \mathrm{MSA}(\mathrm{g})$, and $\mathrm{MSA}(\mathrm{p})$. J. Geophys. Res.: Atmos. 1998, 103, 1657-1678.

(24) Olin, M.; Kuuluvainen, H.; Aurela, M.; Kalliokoski, J.; Kuittinen, N.; Isotalo, M.; Timonen, H. J.; Niemi, J. V.; Rönkkö, T.; Dal Maso, M. Traffic-originated nanocluster emission exceeds $\mathrm{H}_{2} \mathrm{SO}_{4}$-driven photochemical new particle formation in an urban area. Atmos. Chem. Phys. 2020, 20, 1-13.

(25) Petäjä, T.; Mauldin, R. L., III; Kosciuch, E.; McGrath, J.; Nieminen, T.; Paasonen, P.; Boy, M.; Adamov, A.; Kotiaho, T.; Kulmala, M. Sulfuric acid and $\mathrm{OH}$ concentrations in a boreal forest site. Atmos. Chem. Phys. 2009, 9, 7435-7448.

(26) Lu, Y.; Yan, C.; Fu, Y.; Chen, Y.; Liu, Y.; Yang, G.; Wang, Y.; Bianchi, F.; Chu, B.; Zhou, Y.; Yin, R.; Baalbaki, R.; Garmash, O.; Deng, C.; Wang, W.; Liu, Y.; Petäjä, T.; Kerminen, V.-M.; Jiang, J.; Kulmala, M.; Wang, L. A proxy for atmospheric daytime gaseous sulfuric acid concentration in urban Beijing. Atmos. Chem. Phys. 2019, 19, 1971-1983.

(27) Ding, A. J.; Fu, C. B.; Yang, X. Q.; Sun, J. N.; Zheng, L. F.; Xie, Y. N.; Herrmann, E.; Nie, W.; Petäjä, T.; Kerminen, V. M.; Kulmala, M. Ozone and fine particle in the western Yangtze River Delta: an overview of $1 \mathrm{yr}$ data at the SORPES station. Atmos. Chem. Phys. 2013, 13, 5813-5830.

(28) Nie, W.; Ding, A. J.; Xie, Y. N.; Xu, Z.; Mao, H.; Kerminen, V. M.; Zheng, L. F.; Qi, X. M.; Huang, X.; Yang, X. Q.; Sun, J. N.; Herrmann, E.; Petäjä, T.; Kulmala, M.; Fu, C. B. Influence of biomass burning plumes on HONO chemistry in eastern China. Atmos. Chem. Phys. 2015, 15, 1147-1159.

(29) Ding, A.; Nie, W.; Huang, X.; Chi, X.; Sun, J.; Kerminen, V.-M.; Xu, Z.; Guo, W.; Petäjä, T.; Yang, X.; Kulmala, M.; Fu, C. Long-term observation of air pollution-weather/climate interactions at the SORPES station: a review and outlook. Front. Environ. Sci. Eng. 2016, 10, 15 .

(30) Xu, Z. N.; Nie, W.; Liu, Y. L.; Sun, P.; Huang, D. D.; Yan, C.; Krechmer, J.; Ye, P. L.; Xu, Z.; Qi, X. M.; Zhu, C. J.; Li, Y. Y.; Wang, T. Y.; Wang, L.; Huang, X.; Tang, R. Z.; Guo, S.; Xiu, G. L.; Fu, Q. Y.; Worsnop, D.; Chi, X. G.; Ding, A. J. Multifunctional Products of Isoprene Oxidation in Polluted Atmosphere and Their Contribution to SOA. Geophysical Research Letters 2021, 48, e2020GL089276 DOI: $10.1029 / 2020$ GL089276.

(31) Ding, A.; Huang, X.; Nie, W.; Chi, X.; Xu, Z.; Zheng, L.; Xu, Z.; Xie, Y.; Qi, X.; Shen, Y.; Sun, P.; Wang, J.; Wang, L.; Sun, J.; Yang, X.Q.; Qin, W.; Zhang, X.; Cheng, W.; Liu, W.; Pan, L.; Fu, C. Significant reduction of $\mathrm{PM}_{2.5}$ in eastern China due to regional-scale emission control: evidence from SORPES in 2011-2018. Atmos. Chem. Phys. 2019, 19, 11791-11801.

(32) Jokinen, T.; Sipilä, M.; Junninen, H.; Ehn, M.; Lönn, G.; Hakala, J.; Petäjä, T.; Mauldin, R. L., III; Kulmala, M.; Worsnop, D. R. Atmospheric sulphuric acid and neutral cluster measurements using CI-APi-TOF. Atmos. Chem. Phys. 2012, 12, 4117-4125.

(33) Kürten, A.; Rondo, L.; Ehrhart, S.; Curtius, J. Calibration of a Chemical Ionization Mass Spectrometer for the Measurement of Gaseous Sulfuric Acid. J. Phys. Chem. A 2012, 116, 6375-6386. 
(34) Yuan, B.; Koss, A. R.; Warneke, C.; Coggon, M.; Sekimoto, K.; de Gouw, J. A. Proton-Transfer-Reaction Mass Spectrometry: Applications in Atmospheric Sciences. Chem. Rev. 2017, 117, 13187-13229.

(35) Wang, J. L.; Chang, C. C.; Lee, K. Z. In-line sampling with gas chromatography-mass spectrometry to monitor ambient volatile organic compounds. J. Chromatogr. A 2012, 1248, 161-168.

(36) Liu, Y.; Li, L.; An, J.; Huang, L.; Yan, R.; Huang, C.; Wang, H.; Wang, Q.; Wang, M.; Zhang, W. Estimation of biogenic VOC emissions and its impact on ozone formation over the Yangtze River Delta region, China. Atmos. Environ. 2018, 186, 113-128.

(37) Wesely, M. L. Parameterization of surface resistances to gaseous dry deposition in regional-scale numerical models. Atmos. Environ. 1989, 23, 1293-1304.

(38) Wesely, M. L.; Hicks, B. B. A review of the current status of knowledge on dry deposition. Atmos. Environ. 2000, 34, 2261-2282.

(39) Kulmala, M.; Petäjä, T.; Nieminen, T.; Sipilä, M.; Manninen, H. E.; Lehtipalo, K.; Dal Maso, M.; Aalto, P. P.; Junninen, H.; Paasonen, P.; Riipinen, I.; Lehtinen, K. E. J.; Laaksonen, A.; Kerminen, V.-M. Measurement of the nucleation of atmospheric aerosol particles. Nat. Protoc. 2012, 7, 1651-1667.

(40) Xiao, M.; Hoyle, C. R.; Dada, L.; Stolzenburg, D.; Kürten, A.; Wang, M.; Lamkaddam, H.; Garmash, O.; Mentler, B.; Molteni, U.; Baccarini, A.; Simon, M.; He, X.-C.; Lehtipalo, K.; Ahonen, L. R.; Baalbaki, R.; Bauer, P. S.; Beck, L.; Bell, D.; Bianchi, F.; Brilke, S.; Chen, D.; Chiu, R.; Dias, A.; Duplissy, J.; Finkenzeller, H.; Gordon, H.; Hofbauer, V.; Kim, C.; Koenig, T. K.; Lampilahti, J.; Lee, C. P.; Li, Z.; Mai, H.; Makhmutov, V.; Manninen, H. E.; Marten, R.; Mathot, S.; Mauldin, R. L.; Nie, W.; Onnela, A.; Partoll, E.; Petäjä, T.; Pfeifer, J.; Pospisilova, V.; Quéléver, L. L. J.; Rissanen, M.; Schobesberger, S.; Schuchmann, S.; Stozhkov, Y.; Tauber, C.; Tham, Y. J.; Tomé, A.; Vazquez-Pufleau, M.; Wagner, A. C.; Wanger, R.; Wang, Y.; Weitz, L.; Wimmer, D.; Wu, Y.; Yan, C.; Ye, P.; Ye, Q.; Zha, Q.; Zhou, X.; Amorim, A.; Carslaw, K.; Curtius, J.; Hansel, A.; Volkamer, R.; Winkler, P. M.; Flagan, R. C.; Kulmala, M.; Worsnop, D. R.; Kirkby, J.; Donahue, N. M.; Baltensperger, U.; El Haddad, I.; Dommen, J. The driving factors of new particle formation and growth in the polluted boundary layer. Atmos. Chem. Phys. Discuss 2021, 1-28.

(41) Rohrer, F.; Berresheim, H. Strong correlation between levels of tropospheric hydroxyl radicals and solar ultraviolet radiation. Nature 2006, 442, 184-187.

(42) Liu, Y.; Nie, W.; Xu, Z.; Wang, T.; Wang, R.; Li, Y.; Wang, L.; Chi, X.; Ding, A. Semi-quantitative understanding of source contribution to nitrous acid (HONO) based on 1 year of continuous observation at the SORPES station in eastern China. Atmos. Chem. Phys. 2019, 19, 13289-13308.

(43) Hirsikko, A.; Nieminen, T.; Gagné, S.; Lehtipalo, K.; Manninen, H. E.; Ehn, M.; Hõrrak, U.; Kerminen, V.-M.; Laakso, L.; McMurry, P. H.; Mirme, A.; Mirme, S.; Petäjä, T.; Tammet, H.; Vakkari, V.; Vana, M.; Kulmala, M. Atmospheric ions and nucleation: a review of observations. Atmos. Chem. Phys. 2011, 11, 767-798.

(44) Atkinson, R. Gas-phase tropospheric chemistry of volatile organic compounds .1. Alkanes and alkenes. J. Phys. Chem. Ref. Data 1997, 26, 215-290.

(45) Welz, O.; Savee, J. D.; Osborn, D. L.; Vasu, S. S.; Percival, C. J.; Shallcross, D. E.; Taatjes, C. A. Direct Kinetic Measurements of Criegee Intermediate ( $\mathrm{CH} 2 \mathrm{OO})$ Formed by Reaction of CH2I with O-2. Science 2012, 335, 204-207.

(46) Taatjes, C. A.; Welz, O.; Eskola, A. J.; Savee, J. D.; Scheer, A. M.; Shallcross, D. E.; Rotavera, B.; Lee, E. P. F.; Dyke, J. M.; Mok, D. K. W.; Osborn, D. L.; Percival, C. J. Direct Measurements of Conformer-Dependent Reactivity of the Criegee Intermediate CH3CHOO. Science 2013, 340, 177-180.

(47) Newland, M. J.; Rickard, A. R.; Vereecken, L.; Muñoz, A.; Ródenas, M.; Bloss, W. J. Atmospheric isoprene ozonolysis: impacts of stabilised Criegee intermediate reactions with $\mathrm{SO}_{2}, \mathrm{H} 2 \mathrm{O}$ and dimethyl sulfide. Atmos. Chem. Phys. 2015, 15, 9521-9536.

(48) Stone, D.; Blitz, M.; Daubney, L.; Howes, N. U. M.; Seakins, P. Kinetics of $\mathrm{CH}_{2} \mathrm{OO}$ reactions with $\mathrm{SO}_{2}, \mathrm{NO}_{2}, \mathrm{NO}, \mathrm{H}_{2} \mathrm{O}$ and
$\mathrm{CH}_{3} \mathrm{CHO}$ as a function of pressure. Phys. Chem. Chem. Phys. 2014, $16,1139-1149$.

(49) Alam, M. S.; Camredon, M.; Rickard, A. R.; Carr, T.; Wyche, K. P.; Hornsby, K. E.; Monks, P. S.; Bloss, W. J. Total radical yields from tropospheric ethene ozonolysis. Phys. Chem. Chem. Phys. 2011, 13, $11002-11015$.

(50) Malkin, T. L.; Goddard, A.; Heard, D. E.; Seakins, P. W. Measurements of $\mathrm{OH}$ and $\mathrm{HO}_{2}$ yields from the gas phase ozonolysis of isoprene. Atmos. Chem. Phys. 2010, 10, 1441-1459.

(51) Novelli, A.; Vereecken, L.; Lelieveld, J.; Harder, H. Direct observation of $\mathrm{OH}$ formation from stabilised Criegee intermediates. Phys. Chem. Chem. Phys. 2014, 16, 19941-19951.

(52) Hasson, A. S.; Ho, A. W.; Kuwata, K. T.; Paulson, S. E. Production of stabilized Criegee intermediates and peroxides in the gas phase ozonolysis of alkenes: 2. Asymmetric and biogenic alkenes. J. Geophys. Res.-Atmos. 2001, 106, 34143-34153.

(53) Campos-Pineda, M.; Zhang, J. Product yields of stabilized Criegee intermediates in the ozonolysis reactions of cis-2-butene, 2methyl-2-butene, cyclopentene, and cyclohexene. Sci. China-Chem. 2018, 61, 850-856.

(54) Novelli, A.; Hens, K.; Ernest, C. T.; Martinez, M.; Nölscher, A. C.; Sinha, V.; Paasonen, P.; Petäjä, T.; Sipilä, M.; Elste, T.; PlassDülmer, C.; Phillips, G. J.; Kubistin, D.; Williams, J.; Vereecken, L.; Lelieveld, J.; Harder, H. Estimating the atmospheric concentration of Criegee intermediates and their possible interference in a FAGE-LIF instrument. Atmos. Chem. Phys. 2017, 17, 7807-7826.

(55) Wine, P. H.; Thompson, R. J.; Ravishankara, A. R.; Semmes, D. H.; Gump, C. A.; Torabi, A.; Nicovich, J. M. Kinetics of the Reaction $\mathrm{OH}+\mathrm{SO}_{2}+\mathrm{M}$.fwdarw. $\mathrm{HOSO}_{2}+\mathrm{M}$. Temperature and Pressure Dependence in the Fall-off Region. J. Phys. Chem. 1984, 88, 20952104.

(56) Long, B.; Bao, J. L.; Truhlar, D. G. Reaction of $\mathrm{SO}_{2}$ with $\mathrm{OH}$ in the atmosphere. Phys. Chem. Chem. Phys. 2017, 19, 8091-8100.

(57) Blitz, M. A.; Salter, R. J.; Heard, D. E.; Seakins, P. W. An Experimental and Master Equation Study of the Kinetics of OH/OD $+\mathrm{SO}_{2}$ : The Limiting High-Pressure Rate Coefficients. J. Phys. Chem. A 2017, 121, 3184-3191.

(58) Blitz, M. A.; Salter, R. J.; Heard, D. E.; Seakins, P. W. An Experimental Study of the Kinetics of $\mathrm{OH} / \mathrm{OD}(\mathrm{v}=1,2,3)+\mathrm{SO}_{2}$ : The Limiting High-Pressure Rate Coefficients as a Function of Temperature. J. Phys. Chem. A 2017, 121, 3175-3183.

(59) Gentner, D. R.; Worton, D. R.; Isaacman, G.; Davis, L. C.; Dallmann, T. R.; Wood, E. C.; Herndon, S. C.; Goldstein, A. H.; Harley, R. A. Chemical Composition of Gas-Phase Organic Carbon Emissions from Motor Vehicles and Implications for Ozone Production. Environ. Sci. Technol. 2013, 47, 11837-11848.

(60) Gelencsér, A.; Siszler, K.; Hlavay, J. Toluene-benzene concentration ratio as a tool for characterizing the distance from vehicular emission sources. Environ. Sci. Technol. 1997, 31, 28692872.

(61) Fu, X.; Wang, S.; Zhao, B.; Xing, J.; Cheng, Z.; Liu, H.; Hao, J. Emission inventory of primary pollutants and chemical speciation in 2010 for the Yangtze River Delta region, China. Atmos. Environ. 2013, $70,39-50$.

(62) Blocquet, M.; Schoemaecker, C.; Amedro, D.; Herbinet, O.; Battin-Leclerc, F.; Fittschen, C. Quantification of $\mathrm{OH}$ and $\mathrm{HO} 2$ radicals during the low-temperature oxidation of hydrocarbons by Fluorescence Assay by Gas Expansion technique. Proc. Natl. Acad. Sci. U. S. A. 2013, 110, 20014-20017.

(63) Zhong, Q.; Shen, H.; Yun, X.; Chen, Y.; Ren, Y.'a.; Xu, H.; Shen, G.; Du, W.; Meng, J.; Li, W.; Ma, J.; Tao, S. Global Sulfur Dioxide Emissions and the Driving Forces. Environ. Sci. Technol. 2020, 54, 6508-6517.

(64) Balis, D. S.; Zerefos, C. S.; Kourtidis, K.; Bais, A. F.; Hofzumahaus, A.; Kraus, A.; Schmitt, R.; Blumthaler, M.; Gobbi, G. P. Measurements and modeling of photolysis rates during the Photochemical Activity and Ultraviolet Radiation (PAUR) II campaign. J. Geophys. Res.: Atmos. 2002, 107, PAU 5-1. 
(65) Müller, M.; Mikoviny, T.; Feil, S.; Haidacher, S.; Hanel, G.; Hartungen, E.; Jordan, A.; Märk, L.; Mutschlechner, P.; Schottkowsky, R.; Sulzer, P.; Crawford, J. H.; Wisthaler, A. A compact PTR-ToF-MS instrument for airborne measurements of volatile organic compounds at high spatiotemporal resolution. Atmos. Meas. Tech. 2014, 7, 3763-3772. 